


\title{
ALASKA'S GOOD FRIDAY EARTHQUAKE, MARCH 27,1964 A Preliminary Geologic Evaluation
}

\author{
By \\ Arthur Grantz, George Plafker, and \\ Reuben Kachadoorian
}


United States Department of the Interior

STEWART L. UDALL, SECretary

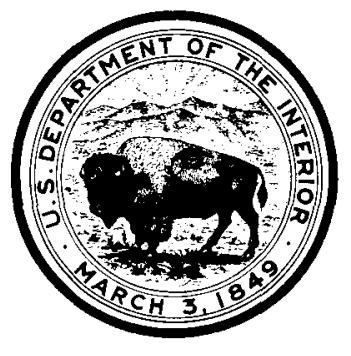

Geological Survey

THOMAS B. NOLAN, Director

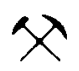

Free on application to the U.S. Geological Survey, Washington, D. C. 20242 


\section{CONTENTS}

Introduction --

Scope of present study

Acknowledgments -

The earthquake and its aftershocks, March 27-30, 1964

The main shock

Aftershocks and their relation to major geologic structures

Areas of tectonic uplift and subsidence

Effects on land

Avalanches and rockslides _.

Cracks, subsidence and mud spouts - 6

Cracks and pressure ridges in lake and river ice

Volcanic activity-10

Water supplies

Damming of rivers-_-

Effects on coasts -

Submarine landslides in fiord deltas and related large waves

Seismic sea waves (tsunamis) -

Waves of unknown origin in Prince William Sound -

Sea life -

Damage to cities, transportation routes, and industries

Cities - -

Anchorage -

Seward

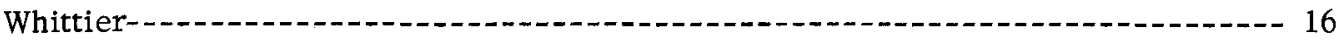

Valdez--_-__._.

Homer-1.

Transportation routes -

The Alaska Railroad -.

Highway routes

Oil, gas, and coal industries - Areas damaged

Areas damaged by seismic sea waves and waves of unknown origin -

Geologic factors influencing earthquake damage -

Compaction --

Lurching -

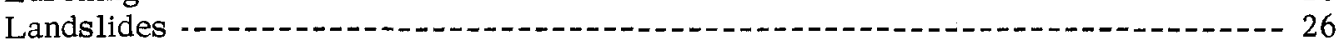

Damage to structures -

Submarine landslides in fiord deltas

Land-level changes -

References--1-- 


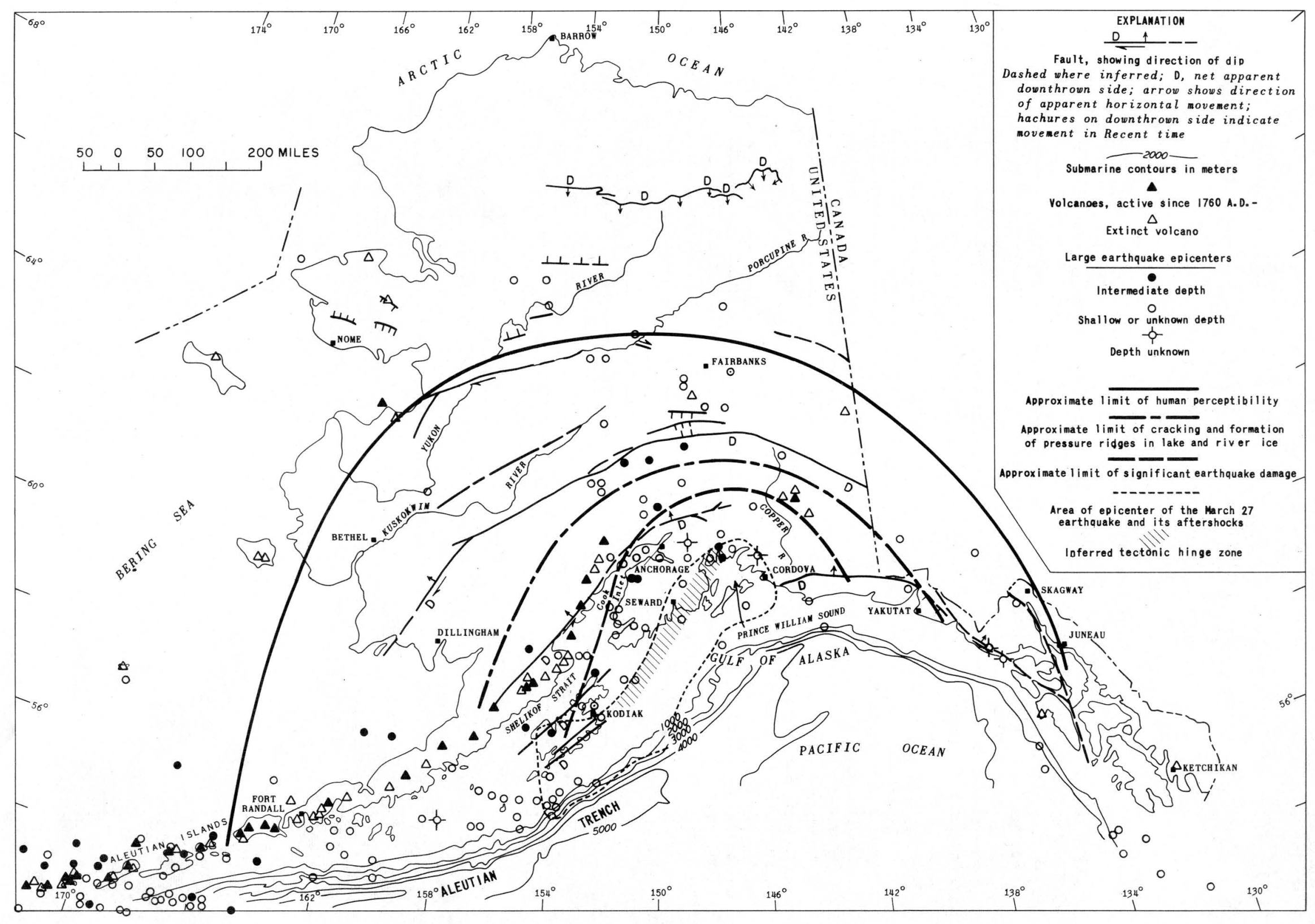

Figure 1. Map of Alaska showing the area of the March 27 earthquake and its aftershocks to March 30, 1964; the area affected by the earthquake; epicenters of previous large earthquakes; major faults; volcanoes; and the Aleutian Trench. 


\title{
ALASKA'S GOOD FRIDAY EARTHQUAKE, MARCH 27,1964 \\ A Preliminary Geologic Evaluation
}

\author{
By \\ Arthur Grantz, George Plafker, and \\ Reuben Kachadoorian
}

\section{INTRODUCTION}

At 5:36 p.m. on Good Friday, March 27, 1964, a great earthquake with a Richter magnitude of 8.4 to 8.6 crippled south-central Alaska. 1 It released at least twice as much energy as the 1906 earthquake which wracked San Francisco, and was felt on land over an area of almost half a million square miles. The earthquake left about 114 dead or missing, and Alaska's Governor Egan has estimated that it will cost one-half and possible three-fourths of a billion dollars to replace the damaged or destroyed private and public property. Many water-front communities, where fishing and shipping were the main industries, lost most of their means' of livelihood.

Had the earthquake occurred earlier, during the school and business day, the loss of life would have been much higher, and had it struck a more populous region, losses of both life and property would have been far greater. And if the seismic sea waves associated with the earthquake had struck the coastal communities of south-central Alaska at high, rather than at low tide, the loss of life and property would have been even greater than the crippling losses that were actually sustained.

This earthquake serves as a reminder that catastrophic earthquakes are a recurring phenomenon in the circum-Pacific region and that man must construct his cities and public works in a manner that will minimize the damage. Basic to the design of earthquake-resistant structures is adequate knowledge of the subsurface conditions upon which the structures are built.

For some time, the U. S. Geological Survey has been studying foundation conditions in urban areas. Reports prepared under this program provide information directly related to the problem of designing and locating large structures in seismic areas. A Geological Survey report several years ago by Miller and Dobrovolny (1959, p. 103-107) contained a warning of the possibility of earthquake-triggered landslides in Anchorage and vicinity. And indeed on March 27 such slides produced most of the damage.

1/All dates and times given are Alaska Standard Time, rather than Greenwich Mean Time which is used in the seismological literature.

\section{SCOPE OF PRESENT STUDY}

The present report is based on a reconnaissance of the earthquake-damaged area made between March 29 and April 9, primarily to obtain firsthand information upon which to plan emergency studies that might aid in reconstruction of the earthquake-damaged areas.

The emergency studies are already underway. Two Survey geologists are now studying the slides in Anchorage that occurred during the March 27 earthquake in order to determine the mechanism of failure which produced them and to assess the danger of future movements that might occur on these landslides and other areas susceptible to landsliding. Two geologists are working with The Alaska Railroad to suggest ways of repairing the $\mathrm{major}$ damage to the lines serving the ports of Whittier and Seward. Most of this damage was caused by ground movement produced by the earthquake. Two other geologists are now studying the ports of Valdez and Seward. These towns are faced with serious problems at their waterfronts, and geologic study is required to resolve them.

In addition to these emergency studies, more detailed follow -up investigations of the geologic aspects of the earthquake and the damage it caused are planned. As these studies are completed, more detailed reports on the geologic implications and effects of the March 27 earthquake will be prepared and the tentative conclusions of the present study will be elaborated upon and perhaps revised in many particulars.

\section{ACKNOWLEDGMENTS}

Most of the logistic support for this investigation was provided by the United States Army, Alaska (US AR AL) - and this under the difficult conditions which existed in south-central Alaska immediately after the March 27 earthquake. We wish particularly to thank Col. M. L. Fallwell, Lt. Col. H. E. Nolde, and their staffs, and the officers and men of the U.S. Army Headquarters Aviation Battalion at Fort Richardson for their efficient and enthusiastic support of our field work. Our special thanks are also due to those many Alaskans, both private citizens and public officials, who related their experiences, provided data, and facilitated our work in many other ways. Many members of the U. S. Geological Survey contributed field 
and office support without which the timely presentation of this preliminary evaluation would have been impossible.

\section{THE EARTHQUAKE AND ITS AFTERSHOCKS,}

\section{MARCH 27-30, 1964 \\ THE MAIN SHOCK}

The epicenter of the March 27 earthquake was at lat $61.05^{\circ} \mathrm{N}$. and long $147.50^{\circ} \mathrm{W}$. (figs, 1 and 2), near the east shore of Unakwik Inlet in northern Prince William Sound. 2f This is a region of high rugged topography with many glaciers, and it is sparsely settled. The nearest sizeable communities are the small cities of Valdez and Cordova, 40 and 70 miles to the east and southeast, and Anchorage, a city of about 50,000 people 80 miles to the west. The focus, or actual point of origin of the earthquake, has been estimated to be about 20 kilometers (about $121 / 2$ miles) below the surface. The shallow depth of the earthquake contributed to the large amount of damage it produced.

The magnitude, or relative energy, released by the March 27 earthquake, estimated from seismograms at four United States stations, ranged from about 8.4 to 8.6 and possibly $8-3 / 4$ on the revised Richter magnitude scale. It was thus greater than that of the 1906 San Francisco earthquake (8.3) and equaled or exceeded that of the largest individual shock of the 1960 Chilean earthquake (8.4). The March 27 earthquake produced significant damage to structures and property over a land area of about 50,000 square miles, and ice was cracked or buckled on some lakes and rivers within an area of about 100,000 square miles (fig. 1). The quake was perceptible to people in at least half of Alaska, and the area of perceptibility, if ocean areas could be included, would exceed a million square miles. (The limit of perceptibility on figure 1 is shown conservatively; the earthquake may have been felt beyond this area under conditions which are particularly favorable for observing small tremors).

The main quake was reported to have lasted about 1 1/2 to 4 minutes in the region that suffered significant damage, suggesting that it occurred along a break or fault of considerable length. Some observers reported an initial short, sharp shake, followed by a strong rolling motion. Observers in the Anchorage area generally reported a north-south or northwest-southeast direction of motion or shaking, but elsewhere too few reports were obtained to permit generalizations.

Independent data on the direction of ground waves were recorded in the pressure ridges and marginal zones of broken ice which formed along the shorelines of some lakes in the area with cracked ice outlined in figure 1 . These features are discussed more fully in

$2 /$ These epicentral and other seismological data concerning the March 27 earthquake and its principal aftershocks given here and below are in part from an unpublished preliminary U. S. Coast and Geodetic Survey data release, and in part from an April 17, 1964 report by the U. S. Department of Commerce, Coast and Geodetic Survey, entitled, Preliminary reportPrince William Sound, Alaskan earthquake, MarchApril, 1964. another part of this report. The largest pressure ridges and widest zones of crushed ice seemed to form along shores that are roughly normal to the reported direction of ground motion, at least in the Anchorage and Knik Arm areas and the Kenai Lowland, although the orientation of these pressure ridges varies widely. Low-altitude areal photographs of frozen lakes taken shortly after large earthquakes could provide clues to the local direction of earthquake induced ground motion.

\section{AFTERSHOCKS AND THEIR RELATION TO MAJOR GEOLOGIC STRUCTURES}

The epicenters of the 52 principal aftershocks before 6:53 (AST) a.m. March 30 are shown on figure 2 and the largest was 6.7 in magnitude. Eleven were of magnitudes greater than 6;10 of them occurred within 24 hours after the initial shock. The aftershocks to March 30 occurred in an area from about 15 miles north of Valdez to about 30 miles south of the Trinity Islands off southern Kodiak Island. All were northwest of the axis of the Aleutian Trench, and almost all lie southeast of the axis of the Kenai-Chugach Mountains and the mountains of Kodiak Island (fig. 2). Only one aftershock occurred northeast of the main shock; the epicenters are most heavily clustered on the northeast and the southwest ends of the aftershock area, and are relatively sparse in the central part.

The aftershocks range in depth from less than 20 $\mathrm{km}$ to about $60 \mathrm{~km}$ (U.S. Coast \& Geodetic Survey data, see footnote 2 , and C. F. Richter, oral communication April 17, 1964). The Coast and Geodetic Survey's report also states (p. 32)..."There is some indication of a slight increase in depth of focus" of the aftershocks "towards land" that is, toward the northwest.

The epicenters of March 27 to 30 lie within a welldefined belt of shallow and intermediate-depth earthquakes which follows the Aleutian Arc from Kamchatka to south-central Alaska, where the arc enters the North American continent (see Gutenberg and Richter, 1954). Most of the earthquakes recorded in Alaska lie within this belt. A characteristic of this earthquake belt, and of others associated with island arcs throughout the world, is that they lie on the concave, generally continental side of the associated deep oceanic trenches. Also, the focal depth of the earthquakes increases from the oceanic trench toward the adjacent continent. This distribution of earthquakes in the Aleutian Arc and Trench is believed by many geologists and geophysicists to indicate that the earthquakes originate in a fault or perhaps a zone of movement which extends with a moderate northward dip from the Aleutian Trench northward beneath the Aleutian Arc. The March 27 earthquake and its aftershocks to March 30 conform to this typical distribution, and it is tentatively inferred that these earthquakes originated along the postulated northwestdipping fault or zone of movement associated with the Aleutian Arc and Trench. Although the epicenters of the main shock and some of the aftershocks are on the mainland, they are no farther inland than the northernmost volcanoes of the Aleutian Arc (fig. 1), and it is noteworthy that the major tectonic trends of 


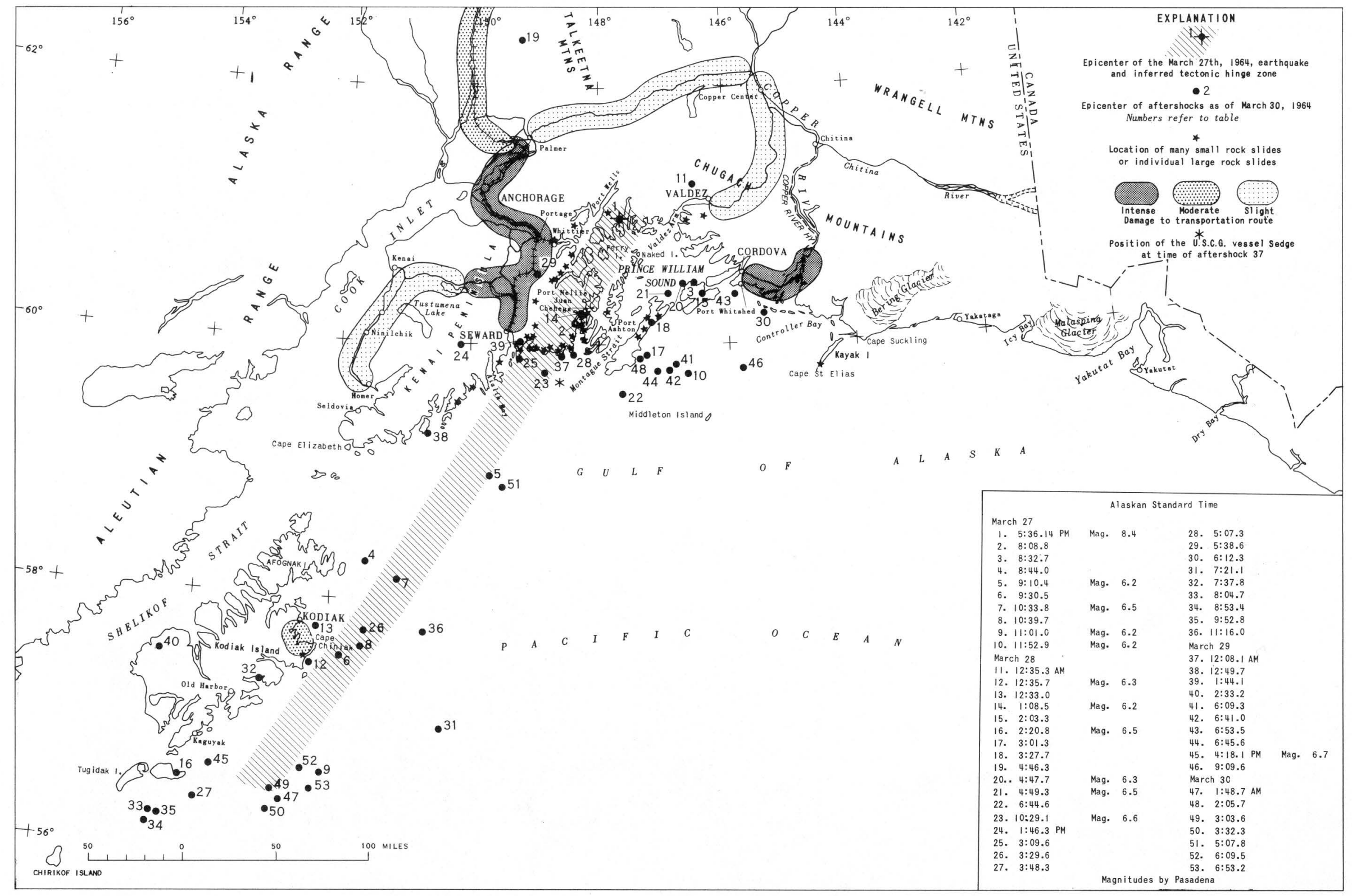

Figure 2. Map showing epicenter, aftershocks, inferred tectonic hinge zone, areas of significant rock slides, and damage to transportation routes. 


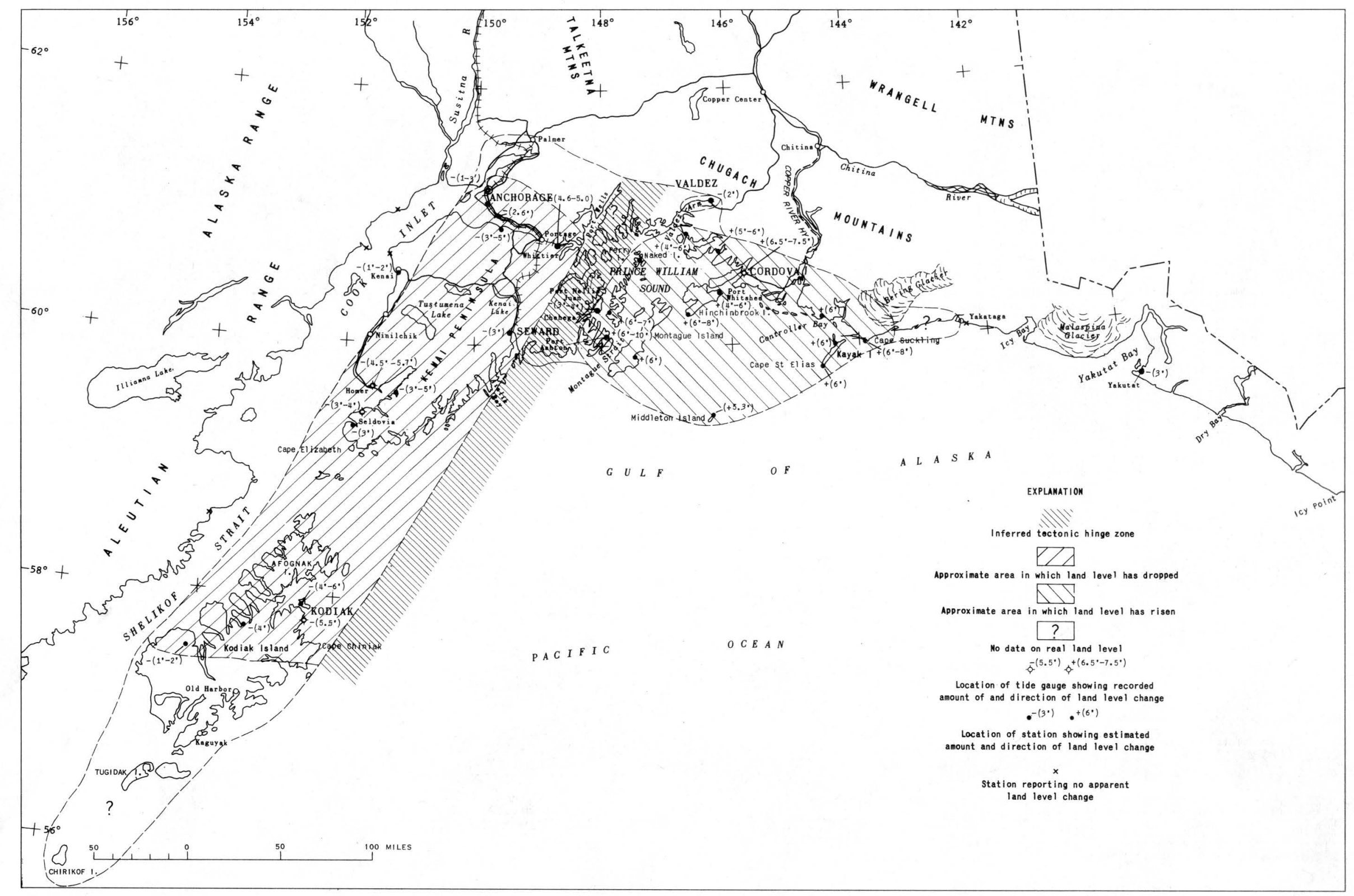

Figure 3. Map showing land-level changes along coast of south-central Alaska. 
southern Alaska bend sharply southwest in the region between the northernmost aftershocks and the northernmost volcanoes.

In contrast to the uniform and characteristic distribution of the epicenters with respect to the Aleutian Arc and Trench, there is no uniform spatial relationship between the epicenters and known continental faults, including the Chugach-St. Elias-Fairweather fault system, the largest in coastal Alaska. The western part of this fault system separates moderately deformed and unmetamorphosed Tertiary sedimentary rocks along the Pacific Coast from a broad terrain of severely deformed and partly metamorphosed Mesozoic marine and some volcanic rocks which underlie Kodiak Island and the Coast Range. Epicenters of the aftershocks to March 30 fall on both sides of this fault system and the trend of the belt of epicenters is oblique to it. Possibly some movement occurred along parts of the Chugach-St. Elias-Fairweather fault system during the March 27 earthquake, but the main earthquake and its aftershocks are probably unrelated to this fault system.

A brief aerial reconnaissance for a surface rupture was made in a broad northeast-trending tectonic hinge zone in the area that contained the epicenter of the main shock and numerous rockfalls and avalanches. This zone lies between the area to the southeast which was tectonically uplifted and the area to the northwest which was tectonically depressed (fig. 3) and is parallel to the trend of the epicentral region, the Aleutian Arc and other major geologic structures in this part of Alaska, and numerous faults, topographic features, and some geologic contacts in Prince William Sound (Condon and Cass, 1958).

Despite these general similarities in trend, the zone between areas of tectonic uplift and subsidence apparently does not follow a major fault boundary between rock sequences of widely differing character as does the Chugach-St. Elias-Fairweather fault system. In the absence of such a major tectonic boundary the surface expression of the faulting which is inferred to have produced the very shallow March 27 earthquake could be either a zone of slight tilting or flexure between the areas of positive and negative tectonic movement, or a surface rupture or fault. No surface rupture or fault line related to the March 27 earthquake was found, but a surface break could easily have been overlooked, especially as new snow had fallen before we reached this area. It is hoped that detailed geologic studies will soon determine whether or not the March 27 earthquake produced fault displacement at the surface.

\section{AREAS OF TECTONIC UPLIFT AND SUBSIDENCE}

Tectonic uplift and subsidence accompanying the March 27 earthquake have affected an area of at least 34,000 square miles in south-central Alaska (fig. 3). East of the tectonic hinge-zone, coastal land levels are up as much as 7.5 feet; to the west of this zone, the land level has subsided as much as 5.4 feet.

Vertical land movements have been measured only in the coastal areas where sea level furnishes a reference datum; the inland limits of the movements cannot be determined without precise leveling. Amounts of vertical movement shown in figure 3 are mainly preliminary estimates obtained from staff tide gauges, tide changes estimated by people familiar with the areas, and observations made by the writers. Records from only five stations (shown by a distinctive symbol on fig. 3) were available from U. S. Coast and Geodetic Survey tide gauges. Work currently underway by the U. S. Coast and Geodetic Survey to install additional tide gauges and re-level existing ones should provide accurate data on the absolute amount and direction of land movement relative to sea level. Wherever possible, the effects of local ground compaction and differential settling of tide gauges were taken into account in evaluating results of tidal reference stations located on surficial unconsolidated deposits.

The major area of subsidence which is shown on figure 3 is a zone trending from northeast to southwest that covers 22,000 square miles, and includes most of the Kenai Peninsula and at least the northern two-thirds of Kodiak Island. The largest amount of confirmed subsidence is at Kodiak, where tide gauges indicate a 5.4 foot drop. Data on land levels in southern Kodiak Island, the Trinity Islands, and Chirikof Island are sparse, but there is some indication that the subsidence diminishes toward the southwest. The amount of subsidence on the Kenai Peninsula decreases westward and is imperceptible at Kenai and Ninilchik. There is no reported change in land level on the west side of Cook Inlet.

The major area of uplift covers at least 12,000 square miles and includes the islands and mainland of Prince William Sound from a line between Chenega and Valdez Arm eastward at least as far as the Bering Glacier and a large segment of the Continental Shelf southward to Middleton Island. Uplifts of 6.5 to 7.5 feet are recorded on the tide gauges at Cordova, and unconfirmed estimates of land uplift in Prince William Sound are as much as 10 feet. Extensive coastal tracts of mud flats, beaches, and reefs throughout the area are now exposed that formerly were seen only at lowest minus tides (fig. 4A). Yakataga, the closest station east of Bering Glacier, reports no change of land level so that the eastern boundary of the uplifted area probably lies in the uninhabited coastal stretch between Bering Glacier and Yakataga.

Possible anomalous areas in the regional pattern are Valdez and Yakutat, where subsidences of 2 feet and 3 feet, respectively, are reported. However, both of these places are situated on deep alluvial fills in which compaction, or settlement of tide reference markers, can be expected. Additional supporting data are needed before these changes in level can be confidently attributed to tectonic subsidence.

Data on land-level changes between the regionally uplifted and downdropped areas are sparse, and it is not possible to determine whether the two major areas are bounded sharply by one or more fault breaks or whether they represent warped crustal segments with a broad zone of flexure between them. The apparent absence of surface breakage within the zone, and a single report of no apparent land-level change at Perry 
Island within this zone, lends some support to the latter possibility.

Existing land-level changes along the coast of southcentral Alaska are likely to be permanent, assuming that all or most accumulated strain energy in the inferred tectonic hinge zone was released by the March 27 earthquake. If further displacement should take place during the aftershock sequence, the amount of movement is likely to be relatively minor, and there is no firm basis on which to predict whether it will be in the same or opposite direction as the initial movement. Three weeks of accurate tidal records at Kodiak Naval Air Station since March 27 indicate that the land level at that locality is stabilized at close to 5.4 feet lower than the pre-earthquake elevation.

\section{EFFECTS ON LAND AVALANCHES AND ROCKSLIDES}

Violent ground motion during the March 27 earthquake triggered thousands of snow avalanches and rockslides throughout the Kenai Mountains, the Chugach Mountains, and the rugged islands of Prince William Sound (fig. 2). One rockslide at the south tip of Kayak Island, approximately 135 miles southeast of the epicenter, killed a Coast Guardsman stationed at the Cape St. Elias lighthouse. Innumerable snow avalanches, rockslides, and landslides blocked or threatened transportation routes between Anchorage, Seward, and Whittier (fig. 2).

Rockslides, some more than 1,000 feet high and of great lateral extent, are most abundant along large segments of the rugged embayed coastline between Resurrection Bay and Montague Strait. Along this coastline there is local preferential distribution of rockslides and avalanches along either northwest-or southeast-facing steep valley walls, but the significance of this observation is not known.

The violence of ground movement in the area is particularly well illustrated near Thumb Cove in Resurrection Bay, where a snow cornice was fragmented and thrown from a peak in a northwest direction and deposited on the mountain slopes below. Large rockslides and avalanches also are numerous along the southeast coast of Montague Island and occur sporadically along the eastern shoreline of the Kenai Peninsula as far north as Port Wells.

One or more huge rockslides on the peaks between College Fiord and Unakwik Inlet may have been the source of a "booming explosion" heard by the crew of the fishing boat Quest, which was in Unakwik Inlet close to the epicenter at the time of the initial earthquake. A group that experienced the earthquake while in Port Wells, immediately west of Unakwik Inlet, reports that ground motion there was so violent that the tops of some trees were snapped off. Numerous fresh rockslides, snow avalanches, and broken ground were seen by the party during the following two days all along the southwest shore of Port Wells and the shores of Passage Canal. New snow had concealed most of these features when the present writers made a reconnaissance flight over the area a week later.

Avalanches and rockslides were surprisingly few in the extremely rugged Chugach Mountains to the northwest, north, and northeast of the epicenter. Scattered snow avalanches were noted as far east as Ragged Mountain, 150 miles from the epicentral area.

\section{CRACKS, SUBSIDENCE, AND MUD SPOUTS}

Numerous ground cracks, areas of subsidence, and mud spouts occurred throughout the zone of damage (figs 5A,B). Cracks were reported as far away as Kaliakh River, near Cape Yakataga, about 190 miles east-southeast of the epicenter. Cracks also occurred in the Copper River delta area, Kodiak, Glennallen, Anchorage, Kenai Lowland, and in other low-lying areas closer to the epicenter.

The major areas of slumping or subsidence were observed at Portage, Homer (fig. 6), Knik Arm, Seward, and Valdez.

Spectacular mud spouts were observed at Portage, in the Copper River delta area, at Controller Bay, and near the Bering Glacier (fig. 5B). Mrs. George Larson of Portage reported that she saw a small mud fountain grow into a sheet of mud about 75 to 100 feet high and about 100 feet long. She also saw geysers of water as much as 50 feet high coming from fractures. Mr. Larson saw a mud and water geyser, estimated to be about 100 feet high, which bubbled for some time after receding.

In the Copper River delta, mud spouts occurred during the initial shock and during some of the aftershocks. Mud deposits were observed on fresh snow that fell after the initial shock of March 27. Seal hunters at Controller Bay, 140 miles southeast of the epicenter, also observed mud spouts, which they described as "fountains of muddy water squirting from the ground."

The frozen surficial crusts of stabilized sand dunes along the Copper River and south of Bering Glacier were severely broken by longitudinal cracks opened by the ground movement. No doubt there are other areas in the damage zone that contain cracks, subsidence, and mud spouts but this report discusses only those observed by or described to, the present writers.

\section{CRACKS AND PRESSURE RIDGES IN LAKE AND RIVER ICE}

Among the many dramatic effects of the earthquake was the precipitous breakage of ice throughout much of south-central Alaska. The area of ice breakage extends from the coast between Yakutat on the east and King Salmon on the west to the crests of the Aleutian Range, Alaska Range, and Wrangell Mountains (fig 1). Lake and river ice throughout much of this area is cracked along the shorelines where the floating ice broke loose. The ice cakes acted as inverted pendulums against which the oscillating ground pounded repeatedly, thereby building up pressure ridges in the ice and snow along the shorelines (fig $5 \mathrm{C}$ ). These pressure ridges, as well as many long cracks across the ice, were in part oriented by shoreline configuration, especially in lakes of irregular shape; however, a large percentage of them appeared to be oriented by ground motion during the earthquake. Approximately east-west to northeast-southwest trends were particularly numerous on the Kenai Peninsula and in 



Figure 4. Photographs of some geologic effects of the earthquake. A, South coast of MIDDLETON ISLAND showing broad uplifted surf-cut reef at base of cliff. B, Landslide damage to The Alaska Railroad at POTTER. C, Avalanches across railroad and highway, TURNAGAIN ARM. D, Seismic sea wave at SEWARD. 

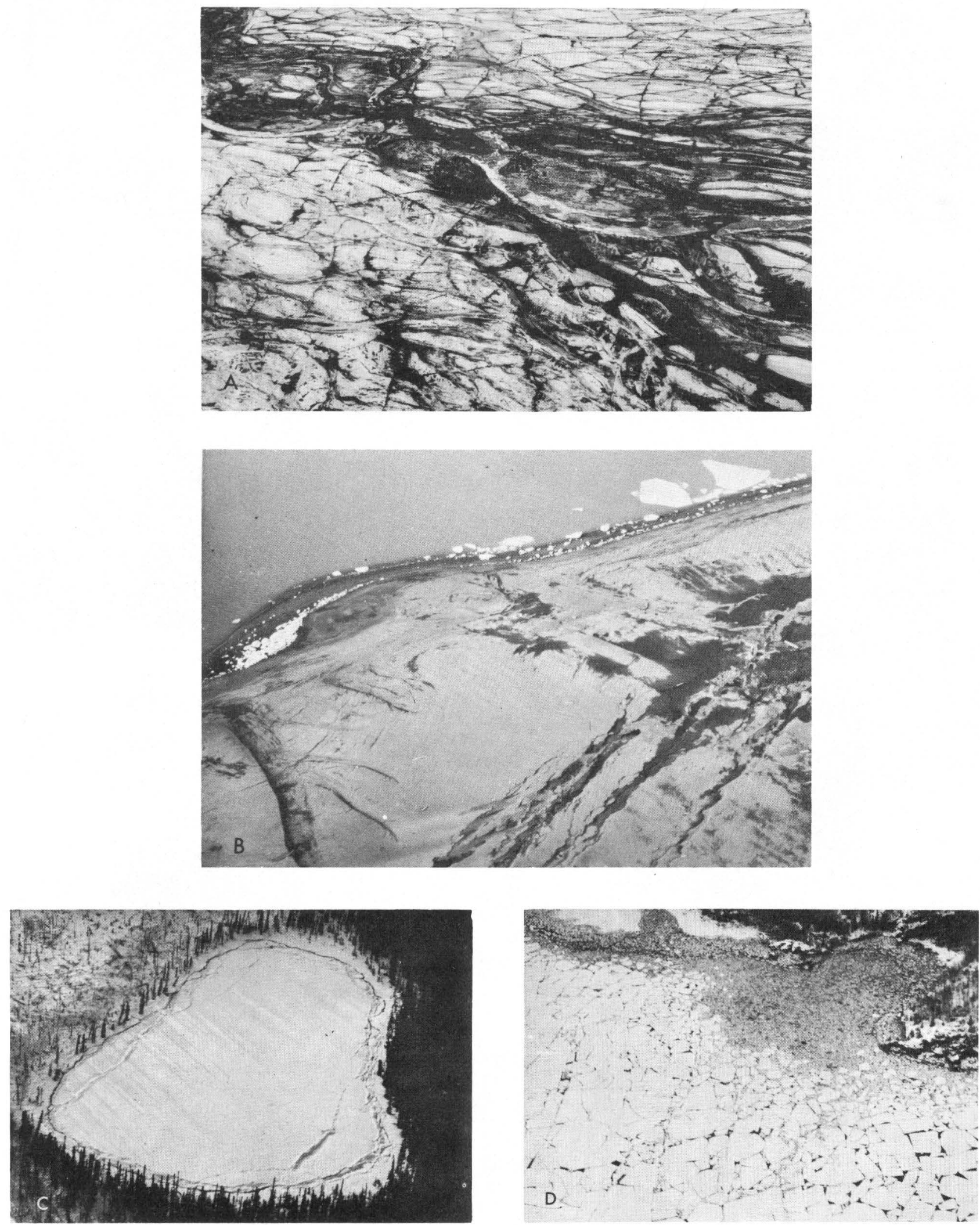

Figure 5. Photographs of fractures and mud spouts in unconsolidated deposits and fractures and pressure ridges in lake ice produced by the March 27 earthquake. A, In glaciofluvial deposits near SKILAK GLACIER. $\underline{B}$, In tidal flat alluvium south of BERING GLAC $\overline{I E R}$. C, On lake in northern KENAI lowland. D, At the head of SKILAK LAKE, Kenai Peninsula. 


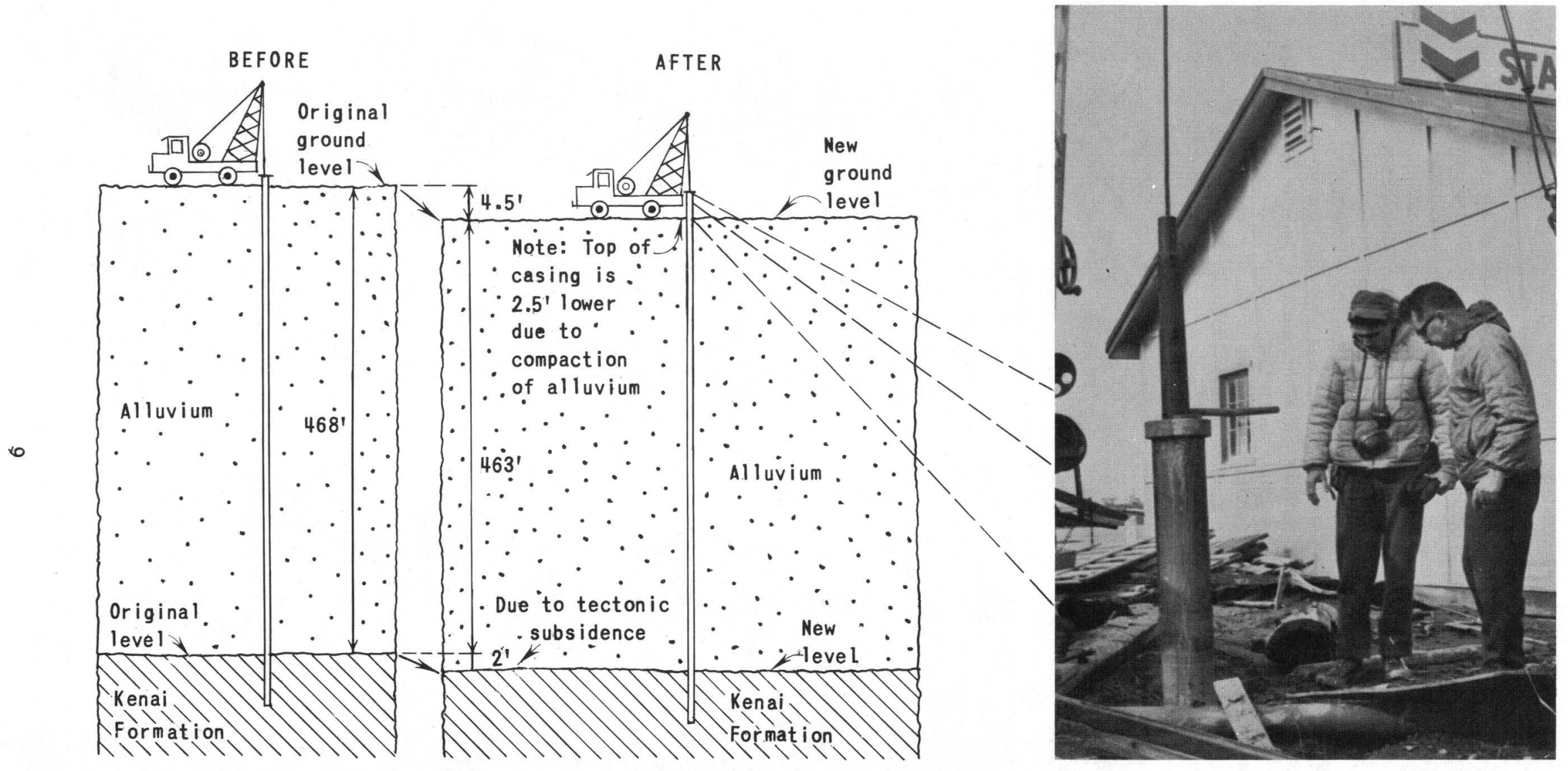

Figure 6. Schematic diagram illustrating 4-5 foot drop of land surface on the HOMER SPIT. 
the Knik Arm area; in the Copper River delta, they were generally east-west. On some of the larger lakes the surface ice was completely shattered by the combination of ground shaking during the earthquake and lake water oscillation during and after the earthquake. Skilak Lake on the Kenai Peninsula (fig 5D) is one example. Cracks and pressure ridges were also observed on river ice throughout this same area. Comparable cracked lake and river ice was described by Davis (1960, p. 491-494) after the April 7, 1958 earthquake in the Koyukuk River basin of west-central Alaska.

\section{VOLCANIC ACTIVITY}

The epicentral region of the March 27 earthquake lies about 100 miles southeast of several active volcanoes in the eastern part of the Aleutian volcanic arc. Airline pilots who regularly fly along or across the volcanic arc report that there was no change in volcanic activity there that could be related to the earthquake.

\section{WATER SUPPLIES ${ }^{3}$}

Water service in the ser iously damaged communities ceased abruptly after the main shock because of disruption of water mains and distribution lines and cessation of electric power for pumping. Wells drilled for public supply--both civil and military--generally survived the quake without serious damage. However, two relatively small wells in the Turnagain area were put out of service by damage to the surface installations,

The March 27 quake caused significant changes in water levels in several artesian wells where measurements have been made periodically for several years. One of these, at Campbell ( 3 miles south of Anchorage), was equipped with a recording gauge which survived the quake. During the quake the surface vibrations and changing water levels combined to produce a band "8-hours" wide and the full length (2 feet) of the chart, at the end of which the water level in the well was 12 feet lower than at the beginning. In the succeeding 12 hours the water level dropped 6 feet farther, and for the next 3 days the water level remained approximately at this level, that is, 18 feet lower than before the quake.

In several other wells in the Anchorage area, the water levels within 5 days after the quake were also significantly lower than they had been before the quake. The amount of this lowering ranged from 3 to 18 feet, and in most wells the levels subsequently rose. Although these changes are attributed chiefly to the earthquake, seasonal fluctuations and the effects of pumping may also have been partly responsible. In Palmer, the effect of the earthquake was observed more clearly at three wells, where water levels on April 1 were respectively $23.6,13.2$, and 6.0 feet lower than on March 24; and where, by April.13, the levels had recovered to within $6.6,2.5$, and 2.0 feet, respectively, of their positions before the quake. In contrast,

3/This statement was contributed by Harold E. Thomas of the U.S. Geological Survey. the water level in one well in Chugiak was 2.7 feet higher on March 31 than it had been on March 24, but by April 9 was lowered 1.7 feet. Such behavior was exceptional--the general rule was a lowering of the water level in artesian wells after the quake, and a subsequent rise.

Measurements of streamflow suggest that streams traversing the Anchorage area lost substantial amounts of water by seepage immediately after the quake. On March 2, the flow of Ship Creek below the diversion dam at the mountain front was 18.2 cubic feet per second; within 4 miles downstream it diminished by 32 percent to $11.3 \mathrm{cfs}$. On March 31 the flow at the dam was $35.9 \mathrm{cfs}$, but measured only $2.0 \mathrm{cfs}$ at the downstream station--an 86 percent loss which may have been caused in part by landsliding. By April 3 the rate of loss between the dam and downstream had decreased to 66 percent and by April 10 to only 15 percent less than at the dam. The flow in Chester Creek, which heads in the lowlands and has a course roughly, parallel to this portion of Ship Creek but south of it, was sharply reduced during the week immediately after the quake--from $12 \mathrm{cfs}$ on March 25 to $4 \mathrm{cfs}$ on March 31 but rose to $6 / 2 \mathrm{cfs}$ on April 3, and more than $13 \mathrm{cfs}$ by April 6 . Taken alone, the loss of water from streams might be attributed to earthquake-cracking of frozen banks and thus to increasing opportunity for seepage. In con junction with the observed changes of water levels in wells, these streamflow measurements suggest that the porosity of saturated materials may have been increased at least temporarily by the earthquake.

\section{DAMMING OF RIVERS}

The great number of landslides and rockslides triggered by the March 27 earthquake could have created potential flood hazards and destroyed salmon fry by blocking the flow of rivers. Consequently, all reports of blocked drainage were promptly investigated by Civil Defense authorities and the intelligence section of the U. S. Army Alaskan Headquarters (US AR AL), but no report of significant stream damming could be substantiated.

\section{EFFECTS ON COASTS}

\section{SUBMARINE LANDSLIDES IN FIORD DELTAS AND RELATED LARGE WAVES}

Prince William Sound is a region of high glaciated mountains intricately sculptured by deep steep-sided fiords that make good natural harbors. At places, especially at their heads, glacial outwash and alluvial streams have built deltas or deltalike platforms into the deep waters of these fiords, and these deltas provide almost the only large level sites for buildings, docking facilities, and railroad yards. These deltas accumulated in deep water, and they form thick prisms of water-saturated, poorly consolidated sediments which contain much glacial silt and clay, and rest on sloping bedrock surfaces. The outer edges of the prisms extend to depths of hundreds of feet and are commonly very steep. In the vicinity of Whittier and Seward, the inclination of the upper part of the submarine slopes at the outer edge of the deltalike deposits, as scaled from U. S. Coast and Geodetic Sur- 
vey Charts, is commonly $30^{\circ}$ to $35^{\circ}$, and such slopes are probably common in the deltalike fiord fillings throughout the Prince William Sound region. Such inclinations are close to the highest slope angles recorded for detrital sediments deposited in quiet water.

Such thick steep-fronted submarine sedimentary fills are not stable under the impact of the strong ground motion produced by large earthquakes, and the March 27 earthquake caused large submarine landslides along the waterfronts at Valdez and Seward, at Thumb Cove in Resurrection Bay, and probably at Whittier (see fig. 7). Similar submarine landslides probably occurred at many other unrecorded localities in the Prince William Sound region. At Seward and Valdez they carried away large parts of the waterfront (see figs. $8 \mathrm{~A}$, and 9) including docks, warehouses, and part of a railroad yard, and left deep water where previously there were docks, buildings, and mudflats. At Seward, for example, water at the site of a former waterfront office is reported to be 30 to 60 feet deep. and 150 to 200 feet deep at a place where it was previously only about 30 feet. Similarly, at Valdez, water in the former dock area is reported to be about 110 feet deep where formerly it was about 35 feet.

The submarine landslides apparently moved downslope quickly en masse, and their movement forced sudden withdrawal of water from the areas which they had occupied. Immediately thereafter large "boils" of muddy debris-laden water rose above the surface of the fiords offshore from the areas that had slid. These "boils" were variously estimated by eyewitnesses to have formed from a few hundred feet to a mile offshore and were described as mounds, cones, or irregular masses of dirty water containing lumber, piling, oil drums, and other shore-derived debris (see fig. 10 and 11). Large waves which did much damage to Seward, Valdez, and Thumb Cove were generated at these "boils", and a "boil" for which no submarine landslide has been specifically identified produced a destructive wave at Whittier. Although these locally generated waves weredestructive, their height and force were substantially less than the seismic sea waves which followed later at Seward and Valvez.

It could not be definitely determined from eyewitness accounts whether the landslide-induced waves produced seiches at Seward or Valdez; possibly a seiche developed at Whittier, where three large waves reportedly inundated the waterfront within 4 minutes. Dr. Merritt Starr and Mr. Robert Hayes of Anchorage reported that a submarine landslide on the south shore of Thumb Cove caused an initial withdrawal of water at the landslide site which returned as a large wave and formed a seiche that reportedly lasted for about an hour. A surface oscillation of the water was also reported in Unakwik Inlet by the fishing boat Quest, but its origin is not known.

\section{SEISMIC SEA WAVES (TSUNAMIS)}

The tsunami generated by the March 27 earthquake struck with destructive force all along the coast of Alaska between the southern tip of Kodiak Island and Cordova (fig. 7). These waves, which can travel at speeds in excess of $400 \mathrm{mph}$ in open ocean, were recorded on tide guages as far away as Japan, Hawaii, and southern California.
The combination of violent earthquake shaking, and battering by earthquake-generated waves of one form or another, left south-central Alaska without a single operative recording tide gauge. The only good record of the tsunami along the Gulf of Alaska through the late hours of March 27 and the early hours of March 28 was kept by personnel of the U.S. Navy Fleet Weather Station at Kodiak. By timing and marking the crest heights of successive waves and estimating the ebb levels and times, they were able to construct a record of the sequence of sea level changes (see fig. 12). The area affected by the tsunami generated on March 27 is grimly defined by the trail of death and destruction along the Gulf of Alaska. However, other than a Kodiak, the times and sequences of wave arrivals in south-central Alaska areknown only from fragmentary accounts of eye-witnesses, most of whom were more concerned with saving their lives and property than with keeping track of the movement of the sea.

The initial tsunami wave was first reported on Kodiak Island at Cape Chiniak (20 miles southeast of Kodiak) approximately 30 minutes after the initial earthquake shock. At that time the Fleet Weather Station issued a tsunami warning, and evacuation of coastal residents in the Kodiak area and the mainland was begun. This prompt action greatly reduced the toll of lives taken by the waves. The water level in the Kodiak area came up like a fast-rising tide, without an initial withdrawal, and peaked 15 minutes later at 22 feet above mean lower low water (adjusted for tectonic land submergence of 5.4 feet during the earthquake). The first wave inundated low-lying portions of the naval base and Kodiak where the high-tide line after the submergence was only about 5 feet above the former mean lower low water. Two more waves followed the first with periods of 55 minutes. The fourth, and highest, wave crested at 30 feet between $11: 16$ p.m. and 11:20 p.m., almost 13/2 hours after the third wave. Successive waves, with irregular periods of between 1 and $1 / 2$ hours, gradually diminished in height and the tsunami died out at about 3:55 a.m. It is of interest to note that smaller wave oscillations attributable to aftershocks felt at Kodiak were superimposed on the larger amplitude tsunami waves. The successive waves inundated large areas of the coastline up to an elevation of 26.5 feet above normal highest tide. (Figure 13 shows the approximate extent of the highest, or fourth, wave in the Kodiak area and the general direction of wave movement).

At Seward, on the west side of Prince William Sound, the first tsunami wave arrived approximately $30 \mathrm{mi}-$ nutes after the earthquake began. The initial tsunami waves that reached Cordova, on the west side of the Sound, arrived at low tide and after the land area had been elevated 6.5 to 7.5 feet by tectonic uplift during the earthquake. Consequently, the first waves, which must have been close to 20 feet high, did not even reach to the now elevated highest high-tide level, which after the earthquake was 21.5 to 22.5 feet above mean lower low water. At approximately 8:20 p.m. the U.S. Coast Guard vessel Sedge ran aground in Orca Inlet near Cordova during a 27-foot drawdown of sea level between successive waves.

The highest wave, which reportedly reached Cordova some time between midnight and 1:00 a.m., rose to about 5 feet above the highest high-tide line, floated 
away houses and boats along the waterfront, and caused extensive damage to piers and docks. Ten cabins at Point Whitshed near Cordova were floated away "in a precise line like coaches of a train" and one of the owners, who had returned to his cabin thinking that the tsunami danger had ended, was lost.

\section{WAVES OF UNKNOWN ORIGIN IN PRINCE WILLIAM SOUND}

A number of highly destructive waves were experienced locally in coastal areas during and almost immediately after the March 27 earthquake. Several of these early waves, notably the first ones that hit Seward and Valdez, were definitely generated by submarine landslides; they are described on later pages. The origin of other waves that were responsible for the loss of at least 43 lives and extensive property damage is not certain; their general distribution and direction are shown on figure 7 . Because Prince William Sound is sparsely populated, the loss in lives and property there from earthquake-generated waves is proportionally extremely high. This tragic loss occurred even though the earthquake and attendant waves came at low tide and probably after the entire eastern part of the Sound was tectonically elevated 4 to 7.5 feet.

The wave that destroyed all but the school and one house in the village of Chenega (locality 7 on fig. 7) and swept away 25 of the 76 inhabitants is described as a "wall of water 90 feet high." This wave, which struck within 3 minutes after the earthquake ended, was preceded by a smaller wave and a pronounced withdrawal of water. The actual wave was at least 35 feet above high-tide level, and runup entered the school building, which stands on a knoll above the village at an elevation of 90 feet. The exceptional height of this wave may be attributed to "focusing" of the onrushing water by refraction around a small group of islands situated in the middle of Knight Island Passage approximately 4 miles southeast of Chenega.

Similar, but much lower, waves were experienced almost simultaneously at the following places: Port Ashton and San Juan (loc. 6 on fig. 7), resulting in the loss of one life; Port Oceanic (loc. 8 on fig. 7 ), where a cannery was damaged and one boat was sunk; Point Nowell (loc. 9 on fig. 7) where two cabins were destroyed and the owner is missing; Perry Island (loc. 10 on fig. 7), where the two Comstock brothers were roughly treated by a wave that rose to 25 feet above sea level and washed 4 feet over a sand bar on which their home is situated; and Fairmount Point (loc. 13 on fig. 7), where a wave broke across a sand bar 15 to 20 feet above high-tide level.

At Port Nellie Juan, where 3 people are missing, dock facilities were apparently damaged by a surge of water that came from the south end of Cullross Passage immediately north of Port Nellie Juan (loc. 11 on fig. 7). Paul Selanoff, who was in a boat near the north end of Cullross Passage at the time of the earthquake, witnessed an ebb-current of "water down through the passage like a big waterfall about 8 to 10 feet high" for a period of about 30 minutes after the earthquake. Evidence of the violence of the southward surge of water at the north end of Cullross Passage is clearly visible locally along the shoreline (fig. 14A).
At an unknown time after the earthquake, a surge of water shot into Valdez Arm and Port Valdez (loc. 14 on fig. 7; fig. 11). The wave overtopped and destroyed a navigation light in Valdez Passage, struck the north shore of Port Valdez near the Cliff mine, was reflected to the southeast shore, which it struck at Jackson Point, and dissipated toward the head of Port Valdez. The wave destroyed wooden buildings at the Cliff mine and deposited debris 170 feet above sea level. Runup reached 220 feet, as indicated by broken and freshly scarred shrubs. At Jackson Point the Dayville cannery was floated away and the wave heaped driftwood to a height of 17 feet above the highest tide level.

Mr. Jackson, who was at sheltered Sawmill Cove outside Valdez Passage (fig. 11), reports that during and immediately after the earthquake the sea withdrew briefly and then rose rapidly to about the highest tide level but that no large waves were observed. The villages of Tatitlek and Ellamar, on the mainland east of Valdez Passage, were sheltered by Bligh Island from destructive waves from the south. Residents there report a 15-foot withdrawal of water immediately after the earthquake; following withdrawal, the water level rose rapidly about 18 feet, approximately to the highest tide level despite a 4 - to 6-foot tectonic uplift of the land during the earthquake. A generally similar sequence of events is reported by eyewitnesses residing on Peak Island, which is in a sheltered location behind the Naked Islands; by Ed Brenner, who was in Port Wells at the time of the earthquake; and by residents of Whittier.

The destructive waves that appeared at widely separated localities in Prince William Sound within minutes after the earthquake tremors ceased must have been generated locally and almost simultaneously. A general impression gained from the scanty data available is that most of the wave damage was due to a general northward surge of water throughout the sound. A movement similar to that of water in a tilted pan could have resulted from the sudden tectonic uplift of the western part of Prince William Sound and the contiguous continental shelf during the earthquake. Seiche waves, local tsunami waves, and landslide-generated waves may have been superimposed on this general movement of water away from the tectonically elevated areas. Detailed studies of the complex pattern of wave effects in Prince William Sound are needed before a satisfactory reconstruction of their origin and movements can be made.

\section{SEA LIFE}

The March 27 earthquake resulted in mass mortality of certain species of deep-water marine fish and shellfish through disturbance of their normal ecological environments.

The most sudden and dramatic effect became apparent on the morning of the 28 th when vast numbers of red snappers, which normally inhabit waters deeper than 400 feet in Prince William Sound 4 , were found

4/According to an oral communication from Dr. N.J. Willimovsky, there are 26 genera of "red snapper" caught in commercial abundance in Prince William Sound. He states that of these, only the genera Sebastolobus and Sebastodes increase in abundance with depth. These two general probably constitute most of the "red snapper" population found dead at the surface following the earthquake. 


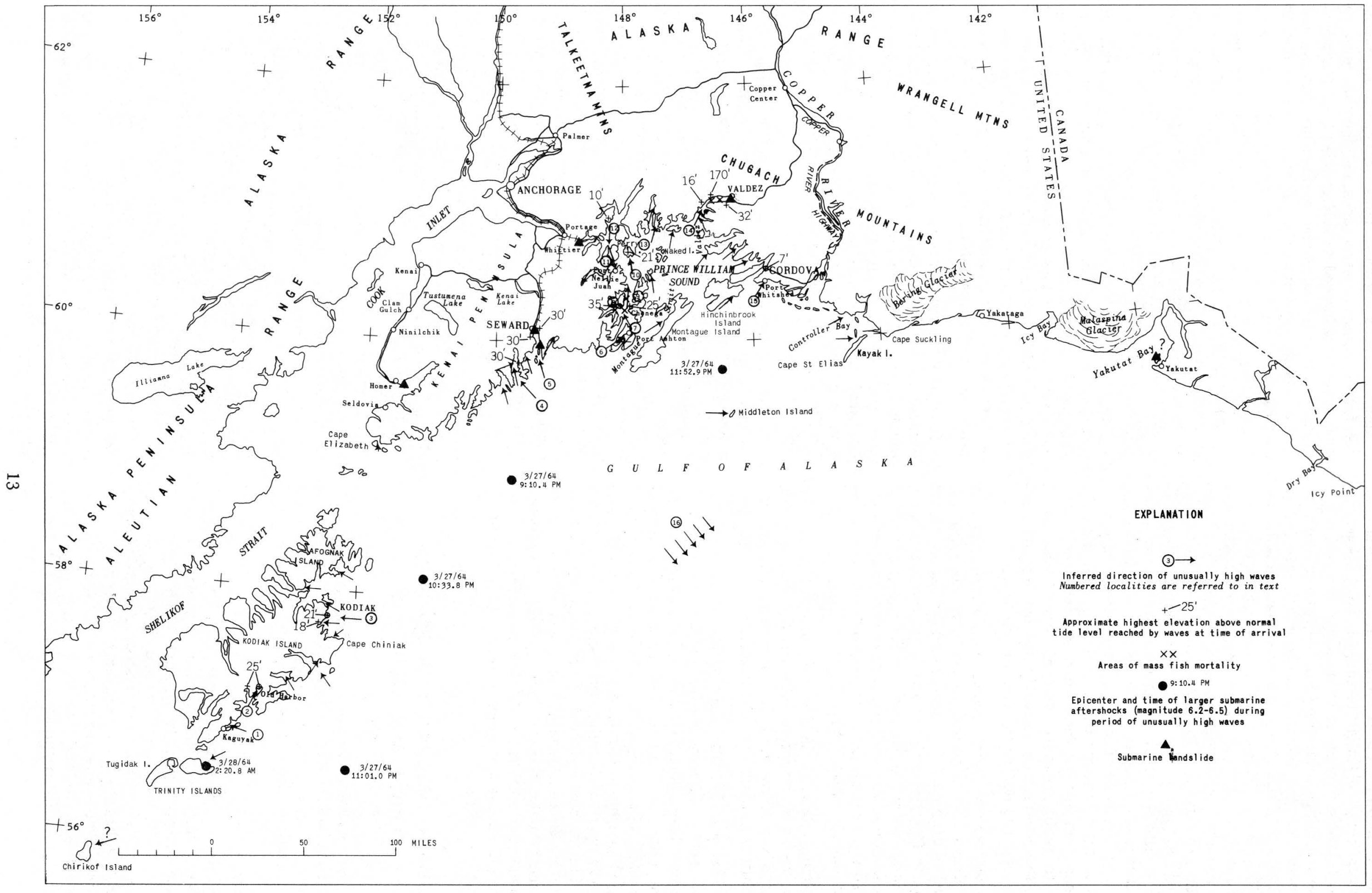

Figure 7. Map showing wave directions, areas of mass fish mortality, submarine landslides, and major submarine aftershocks. 
floating dead on the surface (see fig. 7 for locations). The area between Knight Island, Chenega Island, and Evans Island was covered with snappers according to Cordova Airlines pilot Jim Osborne, who could see the red spots clearly from an altitude of 3,000 feet. Captain Stewart of the Chena observed that the waters of Port Valdez were thick with bloated dead snappers as he steamed out of the port on the 28 th, and the Brenner party reports having seen dead snappers in Port Wells at that same time. Everyone who saw the fish remarked on their great size compared to those normally caught by local fisherman; most estimates agreed that the largest fish weighed about 30 pounds. Unfortunately, none of the fish were submitted to biologists to determine the cause of death. One plausible explanation is that the fish, which are extremely sensitive to rapid pressure changes, were forced up off the bottom where they normally live by turbidity cur rents triggered during the seismic shaking.

The widespread and sudden dumping of sediment over large areas of the bottom is confirmed by the great number of crab pots that were found buried, or partly buried, in Prince William Sound after the earthquake. According to Mr. Baxter of the State Department of Fish and Game, the crab population was not seriously affected and crab catches were approximately the same before and after March 27.

Tectonic uplift during the earthquake left most of the extensive razor-clam beds off the mouth of the Copper River above the reach of normal tides, thereby resulting in their virtual extinction.

The potential effect of the land-level changes on salmon runs in south-central Alaska is difficult to evaluate. There should be little or no effect on upstream migrants. In uplifted areas new intertidal spawning grounds may become available, whereas tidal spawning ground in subsided areas may be lost. The pattern of salmon spawning and fishing in the affected areas almost certainly will be changed, although the net overall effect of loss and gain in Alaska may balance out. Studies are underway by Federal and State agencies concerned with fisheries managment to provide a reliable basis on which to predict possible future changes.

\section{DAMAGE TO CITIES, TRANSPORTATION ROUTES, AND INDUSTRIES CITIES}

The earthquake caused extensive damage to Anchor age and the port cities of Seward, Whittier, Valdez, and Homer. Kodiak was damaged not by the tremor but by inundation after the earthquake.

\section{Anchoroge}

The city of Anchorage, about 80 miles west of the epicenter, sustained the greatest property damage. The Anchorage Daily Times, April 9, 1964, reported that the damage amounted to about $\$ 200,000,000$, that 215 residential homes were destroyed, and $157 \mathrm{com}$ mercial buildings became unusable. Nine people lost their lives or are missing in Anchorage. This damage was from both seismic shock and from landslides triggered by the earthquake, but mostly the latter.
Seismic shock severely damaged several high-rise reinforced concrete structures, and one collapsed. It also severely damaged West High School, some cinder block buildings, and some wooden structures, and caused the control tower at International Airport to collapse.

The earthquake triggered 11 landslides large enough to show on figure 15. Three of these, the Turnagain Heights, L Street, and 4th Avenue slides, caused most of the casualties and catastrophic damage in Anchorage (figs. 17 and 18). A fourth slide destroyed the Government Hill Grammar School.

The L Street slide, that at 4th Avenue, and the one that destroyed the grammar school moved laterally as relatively coherent masses (fig. 16). The heads of these slides were zones of tension into which strips of ground as much as 150 feet wide subsided as much as 15 feet along near-vertical fractures. Narrow zones of compressional buckling at the toes of the slide also caused extensive destruction (fig. 18D).

In contrast, most of the landslide mass at Turnagain Heights broke into a chaotic jumble of rotated blocks which destroyed almost all structures within the slide area (figs. 17A,B). An eye-witness account of the Turnagain Heights slide was furnished the Geological Survey by Mr. E. R. Bush, as reported to him by Mr. Brooke Marston, 1900 Turnagain Parkway, Anchorage, Alaska:

"I was driving my automobile westward on McCollie Avenue when the earthquake occurred. I immediately stopped my automobile and waited until the quake subsided. It appeared to me that the car was rocking from north to south. It rocked so violently that I nearly became seasick. From my car I could observe an earth crack alined north-south and opening and closing from east to west. As soon as the quake subsided I proceeded to drive westward to the corner of McCollie Avenue and Turnagain Parkway. After turning right on Turnagain Parkway and driving approximately 180 feet north, I realized the bluff was gone north of my driveway, which paralleled the bluff in an east-west direction. I got out of the car, ran northward toward my driveway, and then saw that the bluff had broken back approximately 300 feet southward from its original edge. Additional slumping of the bluff caused me to return to my car and back southward approximately 180 feet to the corner of McCollie and Turnagain Parkway. After I stopped at this point, the bluff continued to slowly slide northward as I continued to back my auto southward on Turnagain Parkway. The bluff slowly broke away until the corner of Turnagain Parkway and McCollie had slumped northward.

"It is my impression that the Turnagain Bluff area slumped northward in segments and that much of the southward receding of the bluff occurred after the major earthquake had subsided.

"I was never aware of any unusual noise other than the sounds of people calling for help."

Mr. Milton Norton also was an eyewitness of the Turnagain Heights slide. He stated that sliding started during the shaking and that the bluff peeled away in a succession of narrow slabs. It continued to peel in this fashion until the severe shaking stopped, except for relatively minor sloughing. 
Mr. Bush also furnished the Geological Survey an eye-witness account of the 4th Avenue slide as related by Mr. Chancey Croft of Spenard:

"Mrs. Croft and I weredriving eastward on 4th Avenue between D and C Streets when the March 27, 1964, earthquake occurred. My first impression was that either a flat tire or broken wheel was causing unusual movements of the car. As we approached C Street, I stopped the automobile and we suddenly realized that an earthquake was in progress. The car was rocking quite a bit in a north-south dixection. At this time an earth crack alined east-west began to develop near the center of 4 th Avenue. The crack began to open very slowly about a foot from the left edge of our automobile. We became concerned that the car might fall into this developing chasm and left the car through the right front door at a time which we estimate to be approximately 2 minutes after the first earth shocks were felt. We proceeded to the south sidewalk of 4 th Avenue and stood, throughout the remainder of the earthquake, approximately 40 feet west of the corner of 4 th and C Streets...

"While standing on the sidewalk we observed the north side of 4th Avenue sinking very slowly for several minutes until it finally came to rest at about the time the earth shaking had stopped. We proceeded to help people from the sunken buildings and returned to our automobile, which was still standing, unharmed, about a foot from the edge of the chasm."

Mr. George Boney, who was on the second floor of the Law Building, stated that the building dropped suddenly about 2 minutes after the initial seismic shock. This building, which is at the head of the L Street slide, was damaged when the underlying ground failed in tension, apparently during the earthquake. A 5-foot horizontal displacement was noted on the block in the vicinity of 10th Street.

Numerous cracks were observed in the downtown Anchorage area. On April 2, 1964, control points were put across some of these cracks (generally less than half an inch wide) to determine whether they were opening or closing. Observations over several days indicated that there was no significant change. The scvere aftershocks of April 3, 1964, did not affect the monitored cracks.

\section{Seword}

The earthquake was strongly felt at Seward, but damage from ground motion was minor compared to the massive destruction and 13 deaths inflicted by submarine landslides and large waves (figs, 8A,B,C).

Ground motion in Seward during the earthquake knocked down some chimneys and damaged a few buildings to the extent that they were condemned, but reportedly none collapsed from the shaking. The most serious result of the ground motion was the almost immediate rupture of large fuel storage tanks on the

5/ Among the eyewitnesses who furnished data for this account were John and Roger Eads, William Peterson, Lloyd Heffner, Robert Clark, Harold Drinkall, and Dale Pickett of Seward, and Captain Solibekke of the tanker "Alaska Standard." waterfront; these tanks were quickly ignited, spilling blazing fuel that was later spread by the waves and burned on the water along half a mile of waterfront.

While the tremors were still strong, and, according to some witnesses, about 30 seconds after they had started, 4,000 or more feet of the water-front north of Washington Street slid into Resurrection Bay, taking with it the dock, warehouse, and many fuel storage tanks of the Standard Oil Company and all other waterfront installations and industries north to the area of the San Juan dock and the small-boat harbor (see fig. 9). This submarine landslide, which was probably compound, took with it most of the economic base of Seward. The ground that slid was watersaturated alluvium which fronted Resurrection Bay with a submarine slope near shore of $30^{\circ}-35^{\circ}$. This very steep slope proved to be unstable under the severe shaking of the earthquake.

The new shoreline has a steep slope formed by the main scarp of the submarine landslide, and the water off this shore is in consequence fairly deep. Preliminary soundings furnished by the California Shipping Company indicate that the submarine slope may still be as steep as $30^{\circ}-35^{\circ}$ within the area of the former Standard Oil Co. waterfront, and that an area near the former dock which was 32 feet deep is now about 150 or 200 feet deep. Other preliminary soundings are reported to indicate that one area in the former smallboat harbor has dropped more than 50 feet, and that some former tidelands are now 20 feet deep.

The ground behind the area which slid is broken by many deep open tension cracks which are parallel or subparallel to the new shoreline. A sampling of these are shown on figure 9. A few of these cracks are 12 to 18 inches wide, although most are much nar rower. On a few cracks, vertical displacement of several inches, down on the east or bay side, was noted. These observations suggest that the entire waterfront area with fractures, shown on figure 9, has been extended seaward and dropped slightly, and that this area may be an incipient landslide.

The newly formed shoreline at Seward is unstable, for it is steep-and the ground behind it contains many tension cracks. Until a more stable configuration is reached there will be some further retreat of the shoreline by erosion, sloughing, and perhaps sliding. The possible effects of future great earthquakes on the shoreline with its new configuration require careful study; the possibility that future large submarine landslides may occur there cannot be dismissed lightly.

The submarine landslide drew water from the former shoreline and created "boils" of debris-laden muddy water at a distance from shore estimated by various witnesses to be several hundred feet to a quarter or perhaps half a mile (see fig. 10). Some witnesses reported two "boils" as shown in figure 10, but possibly both were part of the same large feature. In any case, large waves were generated at the "boil" or "boils "and radiated from them at high speed. $3 /$ Before the shaking stopped, or within a few minutes thereafter, these waves hit the north side of Lowell Point, the Seward waterfront, and the north and east sides of Resurrection Bay. They caused considerable damage 
railroad yards. Wave height was estimated by John and Roger Eads to be about 30 feet at the north side of Lowell Point, where trees behind the beach show bruises between 12 and 14 feet above their bases.

About 30 minutes after the first wave (time estimates vary from 15 to 45 minutes) a seismic sea wave entered Resurrection Bay, increased in height as it entered shoaling water, and inundated the low areas of Lowell Point, Seward, and the flats at the head of Resurrection Bay. Local splashes from this wave reportedly reached 100 feet above water level, but in most places its highest trim lines were roughly estimated to be 25 to 35 feet above the water surface, which was at low tide at that time. This wave was higher and more forceful than the first, locally generated, wave and caused most of the wave damage at Seward. It destroyed The Alaska Railroad docks and swept many houses and boats from the vicinity of the small boat harbor into the lagoon north of Seward and onto the flats at the head of Resurrection Bay. It also tossed boxcars, and even a locomotive into windrowlike heaps as shown on figure 9. The path that this wave took through Seward is recorded by steel fence posts and other objects, which were bent in the direction the water traveled. These are shown by arrows on figure 9. Here, as at other places, the fact that the tide was low minimized the damage and loss of life.

The large seismic sea wave was reported by some witnesses to have been followed by large ground swells at intervals of about an hour or an hour and a quarter until about 4:00 or 5:00 o'clock the next morning, but darkness and the demands of self preservation precluded accurate observations of events during the night. Reportedly, none of these later waves or swells were as large as the first seismic sea wave. The passage of what may have been the largest swell was reported by John and Robert Eads, who noticed that after a full tide at Lowell Point at 9:30 p.m., the water receded to about 40 feet below low water in the area of The Alaska Railroad docks at 10:00p.m. Others reported that the water subsequently rose, without producing a violent wave, to a height estimated to be about 20 feet above high water at approximately 11:00 p.m. According to these estimates, the amplitude of this wave was about 70 feet.

\section{Whittier}

The town of Whittier, where 13 people lost their lives or are missing, lies at the head of Passage Canal (fig. 19) and is about 40 miles southwest of the epicenter. Shaking lasted for approximately 2 minutes and had a general east-west direction. Residents on bedrock felt a jarring motion; those on fill or unconsolidated deposits a rolling or "round-andround" motion.

Loss of life and most of the damage at Whittier was caused by the high water and by the fire that followed the earthquake (fig. 8D). Seismic shock was reported to have damaged only the Hodge Building and to have destroyed one oil tank, the slip tower, and the "old" Army dock.

The following sequence of events is based on interviews with residents of Whittier.
The tide was about 1 foot and the water "glassy" before the earthquake. Mr. Farrian Kolb reported that about 2 minutes after the shake started, the water in Passage Canal rose rapidly to an elevation of 25 to 26 feet. It was still "glassy" and did not contain any debris. Mr. M. J. Dixon also reported that the water was "glassy" and estimated that it reached an elevation of 26 feet. The water receded and from 45 seconds to 1 minute later a wave came in. The wave was muddy, contained much debris, and was about 35 feet high when it hit the area of the railroad depot (elevation 26 feet). Mr. McDonald described the wave as a black cloud boiling out of the canal about 50 yards from shore. Mrs. Kolb described it as a wall of water about 30 to 50 feet high that rose about half-way out in the bay. She also stated that she had the impression that something was exploding underneath the water. This wave struck the railroad depot about 8 to 10 feet above the ground surface.

From 30 to 45 seconds after the second rise in sea level (the first actual wave) or within 3-3/4 minutes after the initial seismic shock, another wave occurred. This wave was similar in nature to the one that reached about 35 feet but was 4 to 5 feet lower and did not contain as much debris.

Residents believe that most of the damage was caused by the first wave (second rise of water level). The high water line is shown on figure 19. In the northwest part of Passage Canal, in the vicinity of the CAA station, gravel was deposited as high as 60 feet by the waves. A barnacle-covered boulder of 4 cubic yards was carried about 125 feet by the water and deposited on the track near the railroad depot at an altitude of approximately 26 feet.

\section{Valdez}

The city of Valdez at the northeastern corner of Prince William Sound was severely crippled by the earthquake. Thirty lives were lost when the dock area dis appeared in a sudden submarine landslide during and immediately following the earthquake. An estimated 40 percent of the business district and 10 to 20 percent of the residential district were destroyed and the sewage and water systems were disrupted. The docks, piers, fuel-storage terminal, and small-boat harbor are gone. Two fishing boats that were away from port during the earthquake are all that remain of the local fishing fleet. Photographs of Valdez before and after the March 27 earthquake are shown on figure 20 . The following report is based chiefly on a 1-day reconnaissance examination of earthquake features in the Valdez area by Robert M. Chapman, of the U.S. Geological Survey.

Earth tremors rocked Valdez on March 27 for 3 to 5 minutes. During that time, cracks opened throughout town and the adjacent areas; structures heaved, settled, and shook violently; and people had great difficulty in standing. The most complete destruction and tragic loss of life occurred in the dock area, where the 10,815-ton M. V. Chena, was unloading. Almost as soon as the earthquake tremors were felt, the entire dock area, which was crowded with people, began to sink into the sea and a great "mound" of 

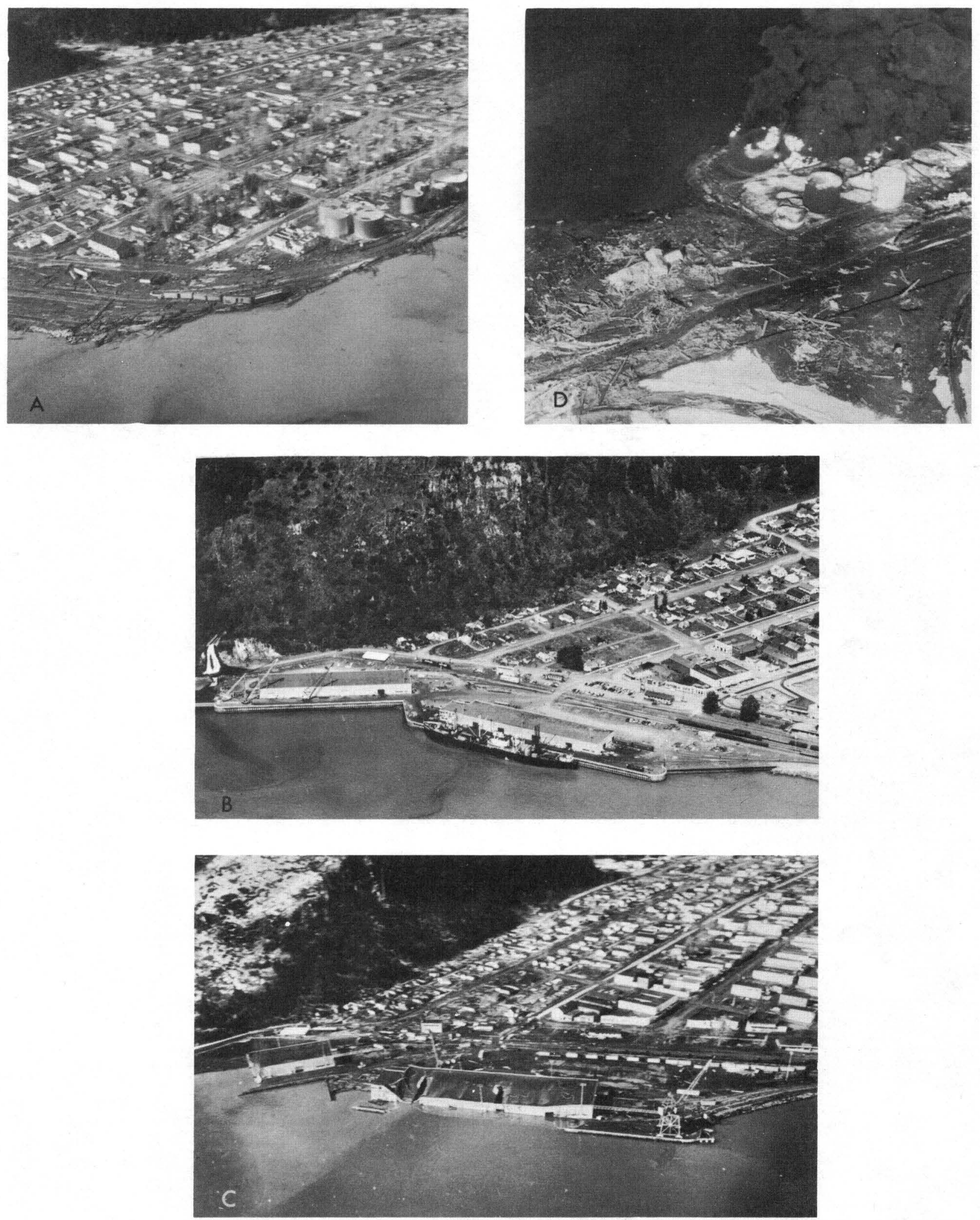

Figure 8. Photographs of wave and submarine landslide damage at SEWARD and WHITTIER. A, Waterfront at SEWARD, showing damage produced by submarine landslides (right side) and large waves (U. S. Army Mohawk photograph). B, C, The Alaska Railroad marginal docks at the south end of SEWARD before and after they were hit by large waves (U. S. Army Mohawk photograph). D, Waterfront at WHITTIER, showing area flooded by large waves (U. S. Army Mohawk photograph). 


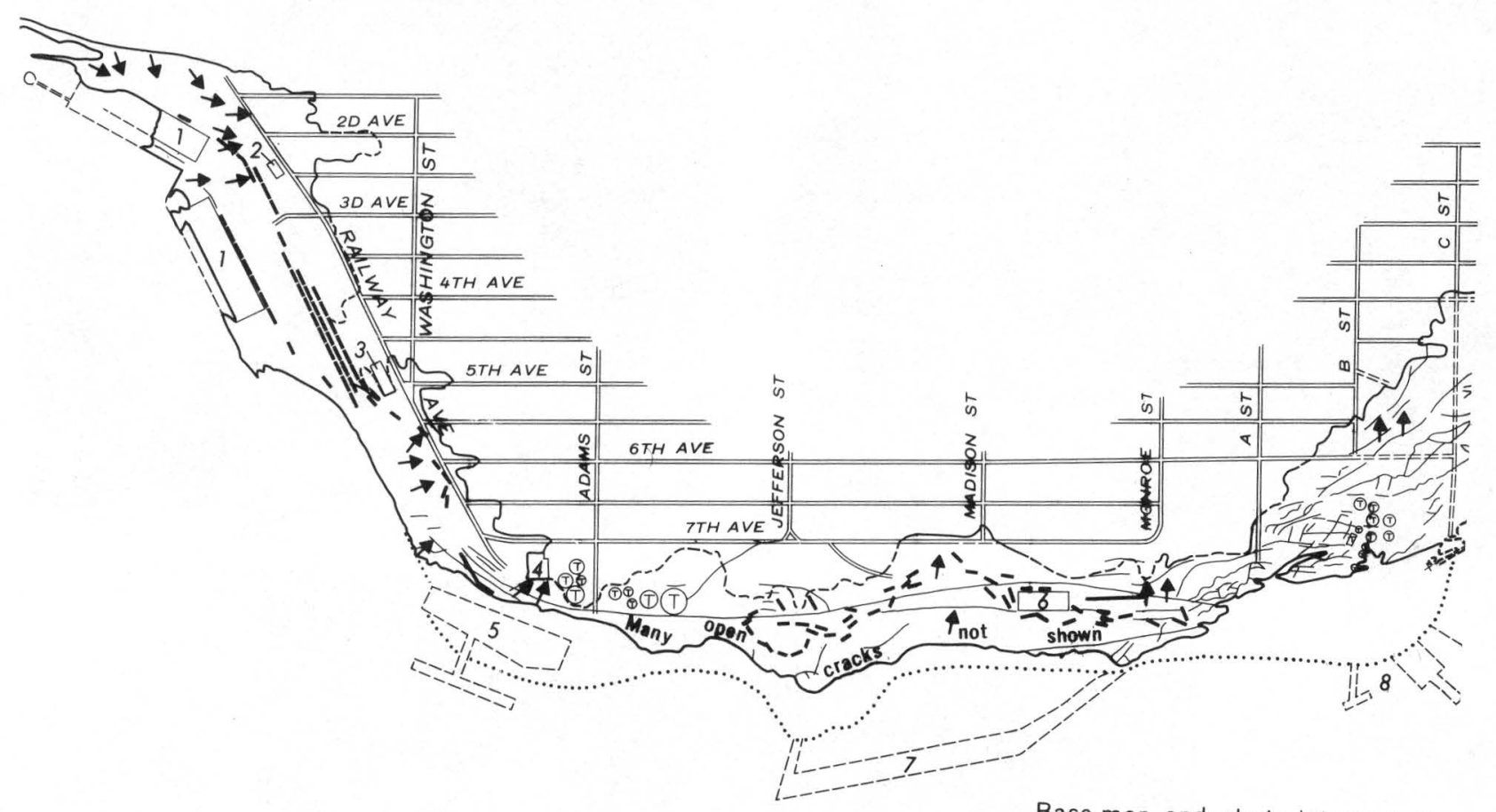

Base map and photo interpretation by W. H. Condon, 1964

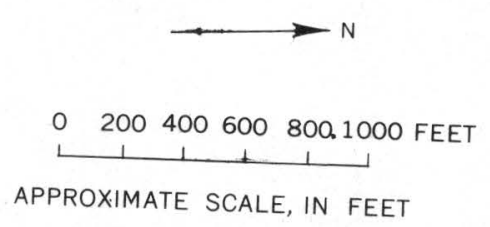

Figure 9. Map of SEWARD showing damage by submarine landslide and large waves. 


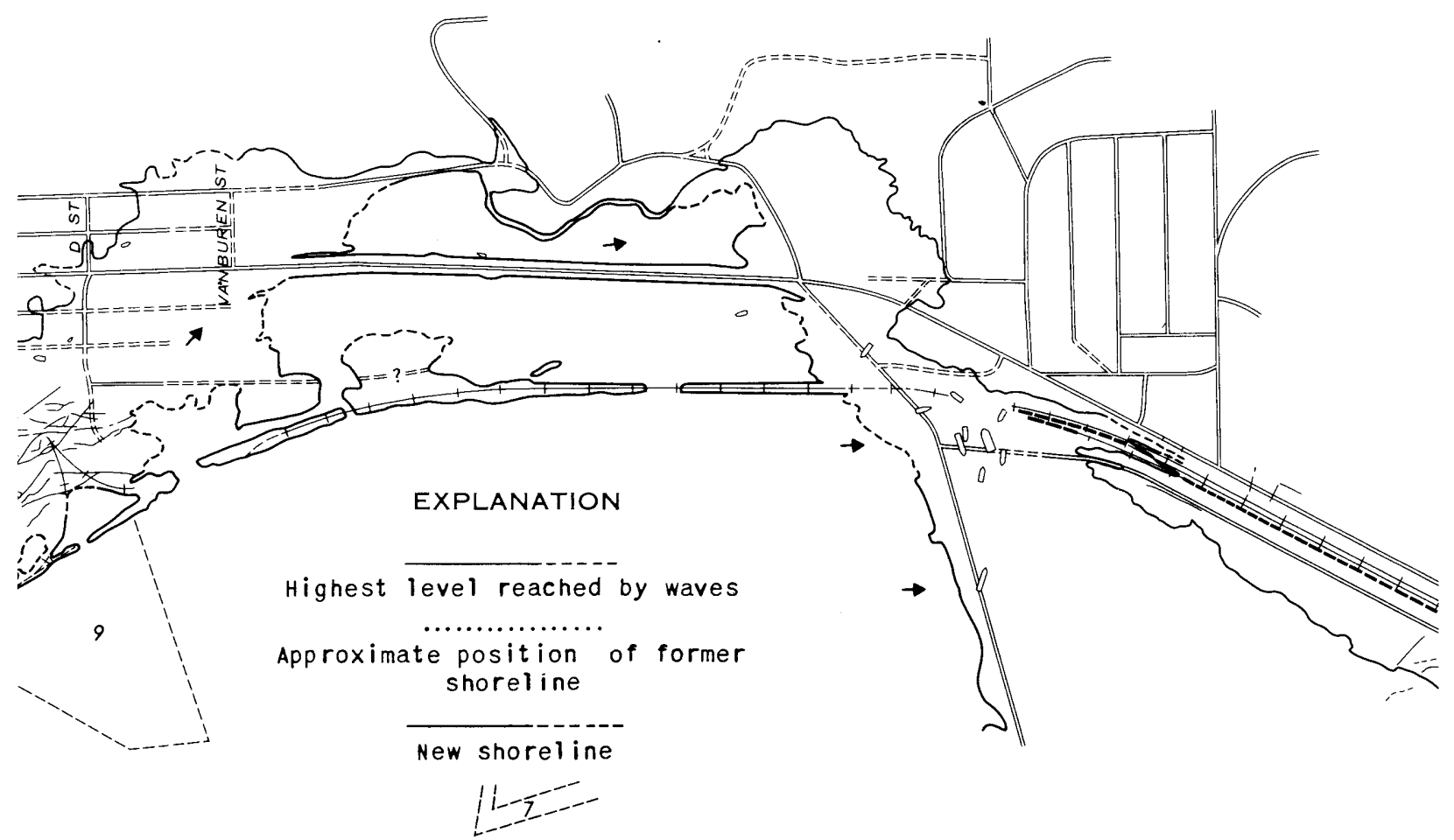

Installations or buildings removed by submarine landslides, and large waves

Direction of wave motion as indicated by bent posts and displacement of objects

$$
\text { Earth-fractures }
$$

More fractures than are shown occur along the water-front between Adams and Monroe streets

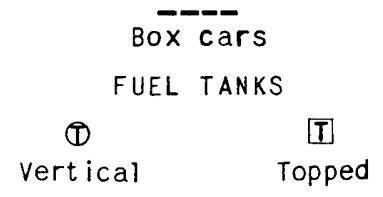

6. Engine House

7. Army Docks and Warehouses (Destroyed)

8. San Juan Dock, Cement Plant, Marine ways (Destroyed)

9. Small Boat Harbor, City Dock, scow Grid (Destroyed) 


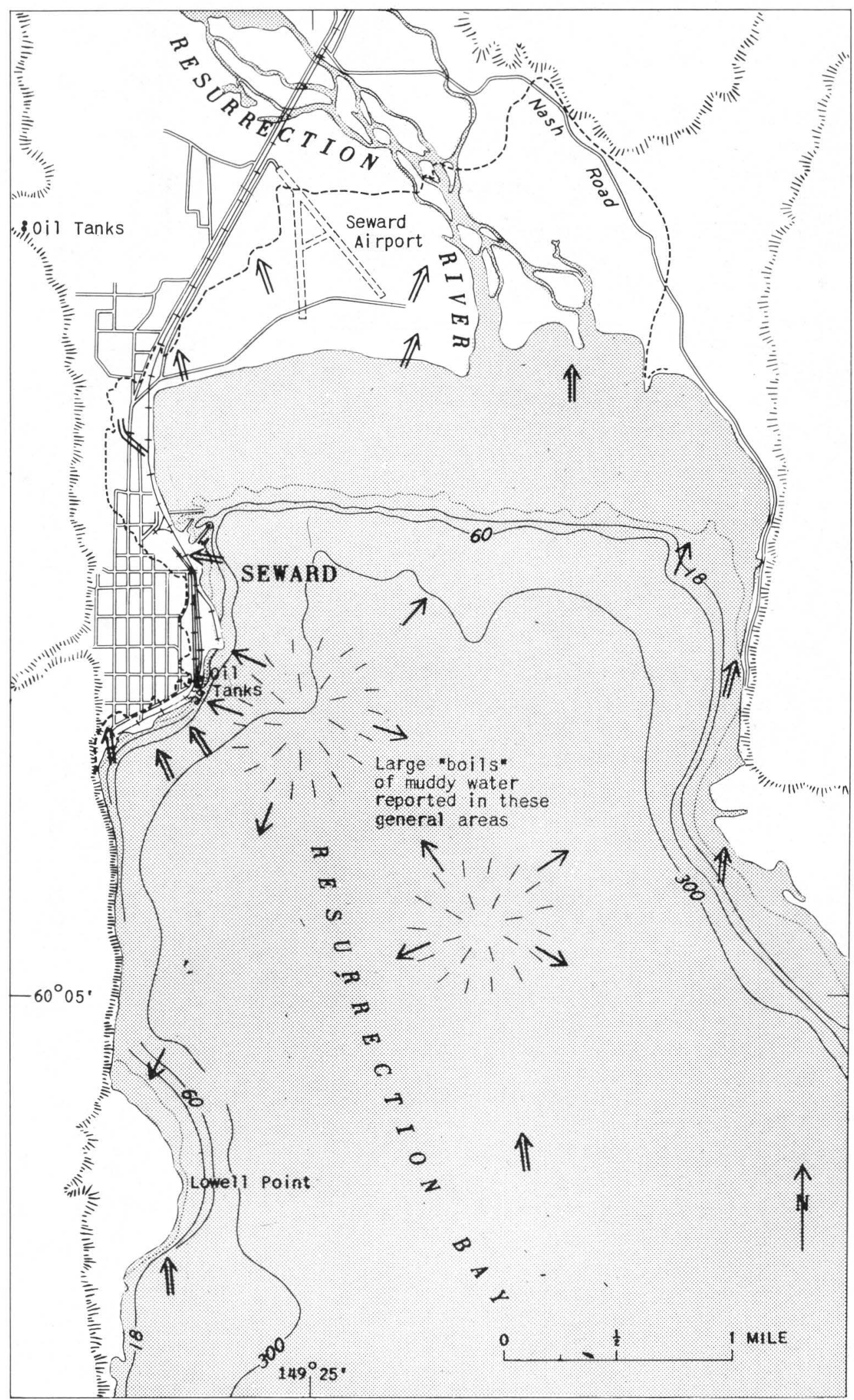

Figure 10. SEWARD and the upper part of RESURRECTION BAY, showing two reported positions of large "boils" of muddy water formed by submarine landslides. 


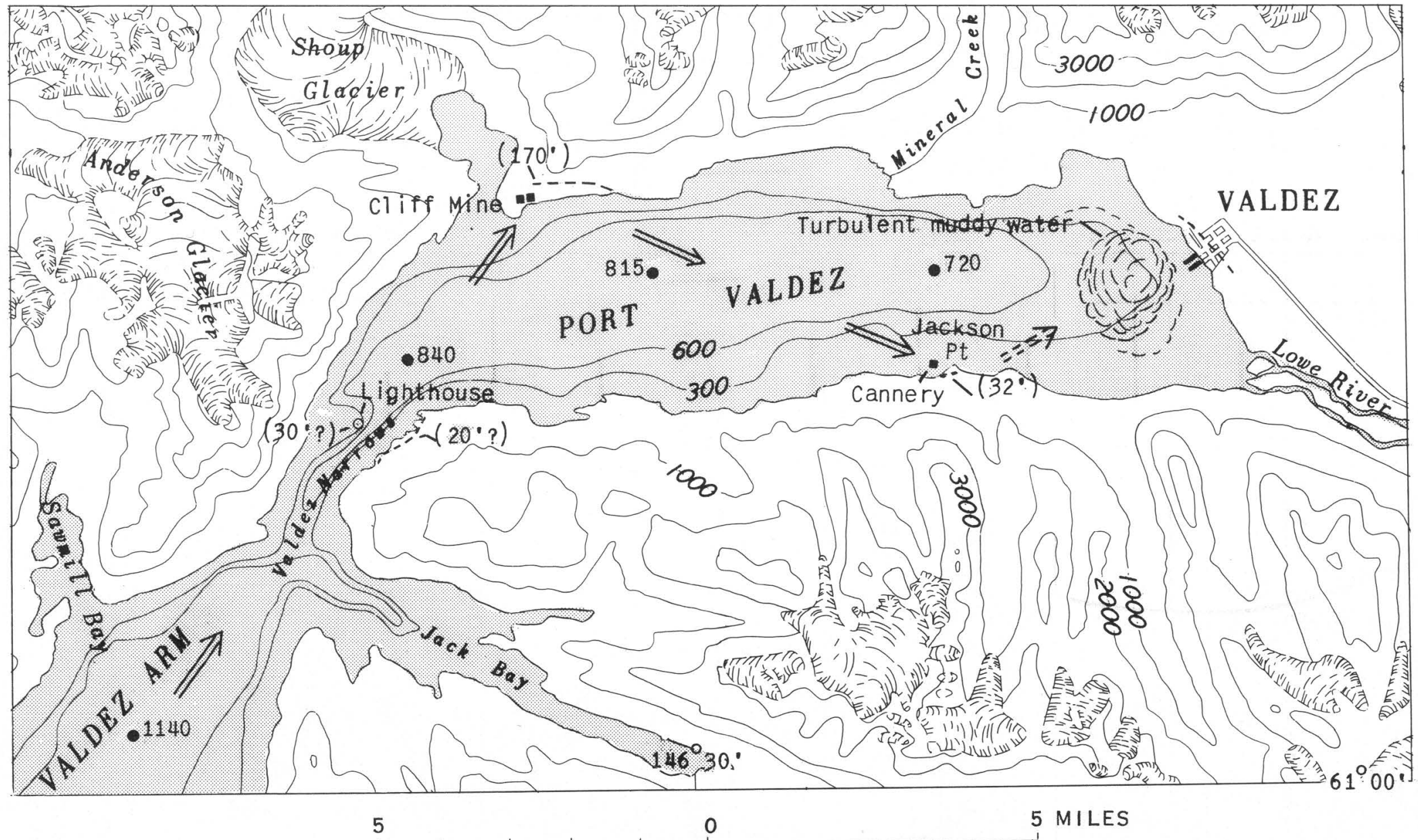

Figure 11. Map of VALDEZ and vicinity. 


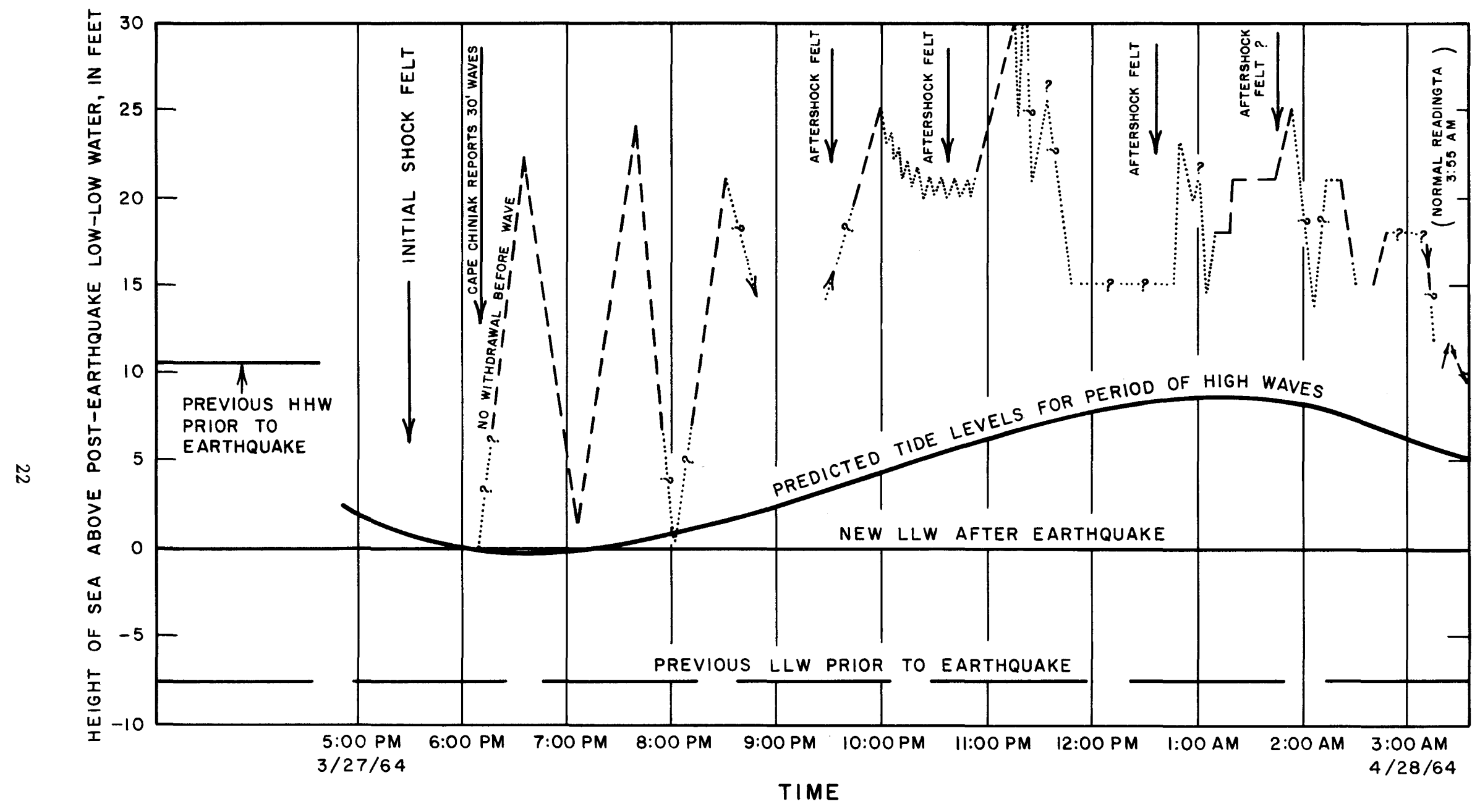

Figure 12. Generalized record of sea-level fluctuations. 

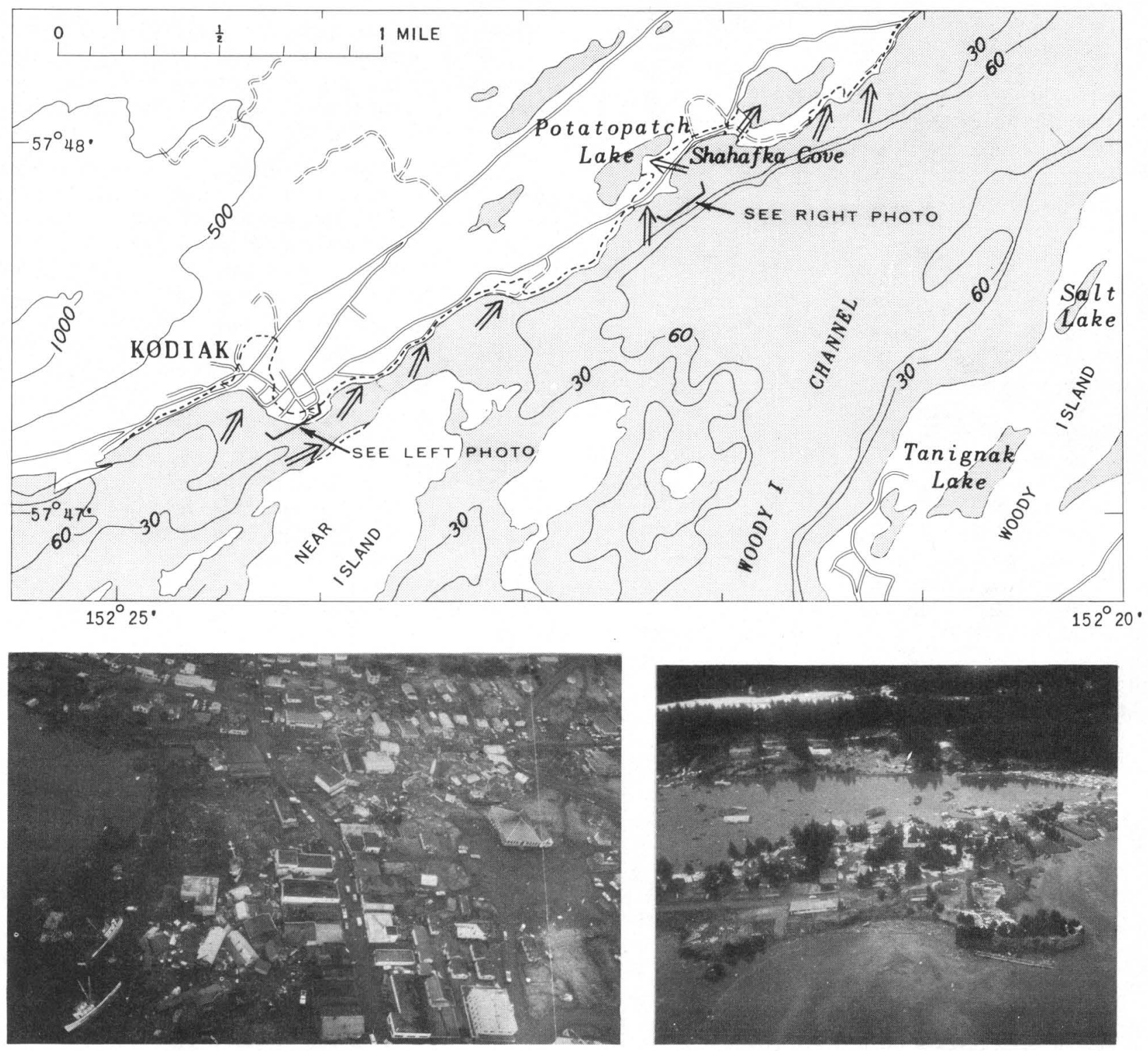

Figure 13. Map of KODIAK and vicinity. 
muddy turbulent water appeared several hundred yards offshore (fig. 11). Within 2 or 3 minutes after the tremors began, the ship was lifted about 30 feet above the pier on an incoming wave and heeled over landward $45^{\circ}-50^{\circ}$ into a "whirlpool" of mud and debris where the pier had been. According to Capt. Merrill D. Stewart, "the ship was slammed on the bottom and rolled wildly from side to side like a rag doll" by a rapid succession of waves before it finally slithered off the mud bottom through wreckage of docks and a cannery to reach the safety of deep water. Approximately 3 hours after the earthquake, fire broke out in fuel storage tanks 0.3 mile southeast of town, throwing flames hundreds of feet into the air; miraculously, no fires broke out in town.

The initial wave that lifted the Chena devastated what remained of the Valdez waterfront within two blocks of shore. During the general confusion that prevailed about 15 minutes after the earthquake began, a smaller wave reportedly inundated the waterfront area, adding to the damage. A third wave followed several hours later at about 11:00 p.m., and the last and highest wave, between 1:00 and 2:00 a.m., flooded the low-lying portions of the city to limits shown on figure 11 . The earthquake occurred approximately at low tide and the last wave coincided closely with the high tide. It is not known whether any of the waves that reached Valdez was the one that left high trim lines at the Cliff mine and Jackson Point (fig. 11), but it could have been the wave that arrived at Valdez almost unnoticed about 15 minutes after the earthquake began. The high-water waves that flooded the lower part of town at 11:00 p.m. and between 1:00 and 2:00 a.m. were probably tsunami waves generated in the Gulf of Alaska.

The city of Valdez is situated on an alluvial fan of unconsolidated sediments that is built out into the head of the deep, steep-sided fiord of Port Valdez. Prior to the earthquake, the seaward slope of the alluvial fan was approximately $15^{\circ}$ near the shoreline. The shaking apparently induced precipitous failure of the unstable, water-saturated alluvium, and a slice 4,000 feet long and 600 feet wide that included the dock area slid seaward. The motion of this large block resulted in the violent upwelling in the middle of the bay, which in turn caused the destructive wall of water that caught the Chena in the first wave. Preliminary soundings along the shoreline by the U.S. Army Corps of Engineers show profound changes in the bottom configuration. At the dock site where there formerly was 35 feet of water there now is 110 feet of water. An area at the small boat harbor that had formerly been exposed at low tide is now covered with water 70 feet deep.

Mr. Ralph Migliaccio, a geologist who examined the upper part of the submarine slide with skin-diving gear, reported that its topography was hummocky, chaotic, and typical of landslides.

Structural damage to buildings was greatest where cracks extended beneath or close to them. Substantial buildings that stond on uncracked ground, such as the electric generating plant and portions of the mental hospital were essentially intact; however, a part of the mental hospital was severely damaged where ground cracks intersected it.
The nature and pattern of cracks observed in the outwash gravel on which the entire town is situated, and subsidence observed in the central part of town all suggest seaward extension and the possibility that a large segment of the town site may be on incipient landslide blocks.

\section{Homer}

Homer, about 160 miles southeast of the epicenter, was shaken violently by the earthquake. Mr. Ralph Cowles stated that the total time of the tremor was from 2 to $2 \frac{1}{2}$ minutes and that its motion was "wavy" and east-west.

Local moderate damage was done in downtown Homer. Homer Spit, a sand bar that extends 5 miles into Kachemak Bay, also suffered damage. During the earthquake, southeast-northwest trending fractures developed throughout much of the spit. Mr. Glen Sewell heard and saw a fracture, 12 to 18 inches wide, coming toward him from the southeast. The fracture passed between his legs, through a building, and continued on into Kachemak Bay. Many of the fractures had vertical displacement, some as much as 8 inches, with the downdropped side toward the coast.

One of the most spectacular and awesome events, as reported by Mr. Dick Hoffer and Mr. Sewell was the disappearance of the small boat harbor on Homer Spit. Within $1 \frac{1}{2}$ to 2 minutes after the tremor started, the harbor disappeared into a "funnel-shaped" pool. A lighthouse once on the harbor breakwater is now 40 to 50 feet below sea level.

Homer Spit has subsided 4 to 6 feet. This subsidence consists of both regional subsidence and local compaction of the unconcolidated sediments that underlie the spit, as shown on figure 6 .

\section{TRANSPORTATION ROUTES}

\section{The Alaska Railroad}

The Alaska Railroad was extensively damaged by the earthquake. Damage was caused by (1) seismic shock, (2) landslides, (3) subsidence, (4) fractures through right-of-way, bridges, and buildings, (5) wave action, (6) fire, and (7) inundation of subsided area during high tide.

Damage was severe to railroad bridges from Matanuska sourh to Seward (fig. 2). Most of the bridges in this 185-mile stretch of the railroad are cambered from compression. At the head of Knik Arm, there was horizontal and vertical displacement of piles and subsidence and shearing of piers. At Portage, 20-Mile Bridge failed due to compression and subsidence (fig. 14B).

Northward from Matanuska to Hurricane, which is half way between Anchorage and Fairbanks, steel jammed tight in most of the bridges. Damage ranged from moderate near Matanuska to slight at Hurricane; north of Hurricane no report of damage has been received.

Large areas subsided at Knik Arm and in the Portage area at the head of Turnagain Arm. In the Portage area, unconsolidated sediments underlying about 4 or 
5 miles of the right-of-way subsided due to a combination of compaction of the unconsolidated sediments and regional subsidence. The amount of subsidence (regional and compaction combined) is unknown, but locally may be as much as 7 feet. During the high tides of April 13 to 14, 1964, much of the right-of-way was inundated as well as the town of Portage. Erosion dur ing these high tides washed out some of the railroad.

Extensive landslide damage occurred along the railroad at Potter (fig. 4B), about 9 miles south of Anchorage, and near the southeast edge of Kenai Lake. The longest slide near Potter is about 1,500 feet long. Additional damage was done by avalanches (fig. 4C).

The Alaska Railroad facilities at Portage, Whittier, Seward, and Anchorage also were damaged--those at Portage by fractures; those at Seward by submarine landsliding and large waves; and those at Whittier by wave action and fire. The railroad shops at Anchorage were damaged chiefly by small landslides.

The railroad spur from Portage to Whittier was severely damaged between Portage and the tunnel, but neither the tunnel nor the mile-long section between the tunnel and Whittier were harmed.

\section{Highway routes}

Severe damage to the highway system, as to The Alaska Railroad, resulted chiefly from destruction of bridges (figs. 14B and 14C) by seismic shock and subsidence of foundations.

The Seward Highway suffered the severest damage, particularly between Potter and Portage, where the Department of Highways reported that 22 bridges were destroyed, apparently by compression followed by collapse. in addition to collapsed bridges, numerous snowslides crossed the highway between Potter and Seward (fig. 4C). As on the railroad, compaction and subsidence occurred in the Portage area.

Damage to the Glenn Highway between Anchorage and Glennallen was minor except at the head of Knik Arm, where the bridge piers were damaged. In addition, two snowslides were triggered south of the bridge crossing Knik Arm.

The Sterling Highway between Moose Pass and Homer underwent minor cracking and settling of fills. The highway bridge crossing the outlet of Kenai Lake was destroyed, however.

The Richardson Highway between Glennallen and Valdez was little damaged, although the Department of Highways reports that part of the road between Valdez and Keystone Canyon, about 20 miles east of Valdez, is "wavy."

Some sections of the highways near Kodiak were severely damaged by both seismic shaking and seismic sea waves.

On the Copper River Highway, damage was severe. The Cordova Times (April 2, 1964) reported that between Eyak River ( 4 or 5 miles east of Cordova) and Mile 13 there were "cracks 6 to 8 inches wide across the road at intervals of about 75 feet." Locally, some spots sank several feet and "most of the roadway sank about 2 feet, leaving all bridges that amount higher than the roadway." The Times also states that a Depart- ment of Highways Engineer, Mr. Arlan Davis, reported that "it appears that serious damage was inflicted on every bridge, including the famous Million Dollar Bridge, which has one end of the northern span in the river [Copper River]." The abandoned railroad bridge near Abercombie Rapids on the Copper River, about 15 miles north of the Million Dollar Bridge, has been damaged (fig. 14C). This bridge was to be part of the highway system.

\section{OIL, GAS, AND COAL INDUSTRIES}

The petroleum industry, Alaska's largest mineral industry, is centered on the Kenai lowland, within the area of damage delimited on figure 1. The oil refinery, tanks, and docks at Nikiski sustained some damage, but there was no important delay in production. The wells in the Swanson River oil field and the Kenai gas field were reportedly not damaged, although some leaks and breaks occurred in pipelines.

Coal mines, both those in the Matanuska Valley at the fringe of the area with significant damage and those in the Alaska Range beyond the area with significant damage, escaped in jury during the earthquake, and production was not interrupted. However, rail transportation from the mines to Anchorage was disrupted for several days.

\section{AREAS DAMAGED BY SEISMIC SEA WAVES OF UNKNOWN ORIGIN}

In Alaska extensive damage from seismic sea waves generated by the March 27 earthquake, and possibly by its early aftershocks, was confined to communities on Prince William Sound and the southeast coast of the Kodiak Islands; those on the Alaska Peninsula and in southern Alaska east of the Copper River delta escaped in jury. These waves also caused casualties and major damage in British Colombia and California.

Especially hard hit in the Prince William Sound area were Valdez, Seward, and Whittier, discussed above (fig. 4D). Chenega, a native village of 76 people of whom 25 were drowned, was hit by a large wave of unknown origin, and large waves destroyed property at a number of other localities on Prince William Sound and killed a total of six people at Port Nellie Juan, Port Ashton, Point Nowell, and Whitshed. An abandoned cannery was destroyed in Port Graham, near Cape Elizabeth.

In the Kodiak Islands, the city of Kodiak and Kodiak Naval Base as well as several small outlying communities on the southeast side of these islands were severely damaged by seismic sea waves, and 19 people are reported dead, or are missing and presumed dead. The native village of Kaguyak was almost completely destroyed, and that of Old Harbor will require extensive reconstruction. Especially serious to all of the damaged communities is the loss of many fishing boats, sea-food processing plants, and other waterfront installations which are the mainstay of their economy (fig. 14D).

\section{GEOLOGIC FACTORS INFLUENCING EARTHQUAKE DAMAGE}

Geologic factors played the chief role in determining the distribution of damage from the earthquake. They 
controlled the distribution of fracturing, compaction, lurching, and landslides, and thereby the distribution of damage to structures. Where these factors are taken into account in locating and designing buildings and structures, the damage wrought by large earthquakes will be greatly reduced. For example, fractures or cracks developed chiefly in the unconsolidated deposits, and structures on such deposits also suffered more damage from shaking because ground motion in unconsolidated deposits is greater than in bedrock.

\section{Compaction}

Extensive areas of unconsolidated deposits were compacted by the seismic shock. Although compaction of the sediments is widespread, time permitted a study only of Homer Spit and the Portage area.

Homer Spit, extensively used for recreational and business purposes, has subsided to the extent that much of the spit is now inundated during high tides. According to Mr. H. A. Thorne of Homer, who was drilling a water well about 100 yards from the continuous-recording tide gauge at the end of Homer Spit, the spit is underlain by the following unconsolidated deposits:

0 to 200 feet - - silt, sand, and gravel
200 to 289 feet - - sand
289 to 321 feet - - marine sand and clay
321 to 462 feet - - - soft clay, locally mushy
462 to 468 feet - - hard clay
468 to 477 + feet - - Kenai(?) Formation

The total subsidence indicated by the tide gauge is from 4.5 to 6 feet. For purposes of illustration, the conservative figure of 4.5 feet was used in figure 6. Based on pre-earthquake and post-earthquake conditions at the water well, the unconsolidated sediments compacted about 2.5 feet. The remaining 2 to 3.5 feet of subsidence is regional.

The total amount of subsidence at Portage has not been clearly established. However, on the basis of the meager information available, there has been some compaction. The following unconsolidated deposits underlie Portage, as shown in the log of a water well at the Union Oil Station:

$$
\begin{aligned}
& 0 \text { to } 20 \text { feet }- \text { - sand and gravel } \\
& 20 \text { to } 425 \text { feet }- \text { - clay } \\
& 425 \text { to } 426 \text { feet }- \text { - sand } \\
& 426 \text { to } 600 \text { feet }- \text { - clay }
\end{aligned}
$$

The maximum total subsidence in the Portage area may be as much as 7 to 8 feet, half of which is probably due to compaction of the unconsolidated deposits. The railroad's 20-Mile Bridge rests on piles about 60 feet deep. The right-of-way to the bridge approaches has subsided from 1 to $11 / 2$ feet more than the bridge (fig. 14B). Thus, the top 50 to 60 feet of the unconsolidated material has compacted relatively more than the material below the piers. This is probably due to loss of volume by the extrusion of water during the seismic shaking.

\section{Lurching}

Lurching in the unconsolidated material displaced the highway 3 feet in the Portage area and at Knik Arm displaced several piles as much as 10 feet horizontally. No such displacement was observed in bedrock.

\section{Landslides}

Most, if not all, of the destructive landslides were restricted to unconsolidated deposits. These include the landslides in Anchorage and the railroad landslide at Potter. The lands lide crossing the railroad at Kenai Lake was not observed on the ground so it is not known whether the slide is in bedrock or in unconsolidated material. Locally in the Portage area the unconsolidated sand, silt, and clay underlying the railroad bed flowed and failed completely.

The Bootlegger Cove Clay (Pleistocene) underlies Turnagain Heights, L Street, 4th Avenue, Government Hill, Alaska Native Hospital (fig. 19B) and other areas in Anchorage where landslides occur. This clay for mation failed in the Turnagain Heights, L Street, and 4th Avenue slides and it probably failed in the other landslide areas as well.

Miller and Dobrovolny (1959) describe the Bootlegger Cove Clay as a "..light-gray to dark-greenish-gray silty clay that contains layers or lenses of medium sand." The clay has thin laminations ranging in thickness from 0.25 to $1.0 \mathrm{~mm}$. Over 80 percent of the grains that make up the Bootlegger Cove Clay are smaller than fine-sand size. A single, apparently typical, grab sample of the Bootlegger Cove Clay taken from the Turnagain Heights slide during the present study contained 61 percent silt, 25 percent clay, and 14 percent very fine sand. The clay fraction was found by $\mathrm{x}$-ray diffraction analysis to be dominated by chlorite, illite, and fine grained quartz and feldspar, and to closely resemble many samples of glacial rock flour from south-central Alaska.

The railroad landslide at Potter was in glacial ground moraine consisting of gravel, with pebbles generally less than three-fourths of an inch in diameter, overlying an older ground moraine consisting predominantly of silt and clay. Failure occurred chiefly in the finer grained moraine. Numerous seeps were noticed near the base of the coarse-grained till several days after the earthquake.

\section{Damage to structures}

The type and thickness of the underlying deposits was, in large part, responsible for the different degrees of damage suffered by many of the structures during the earthquake. In the Anchorage area structures that are underlain by a thin layer of glacial outwash gravel overlying the Bootlegger Cove Clay or underlain by silt were more severly damaged than those underlain by a thicker layer of gravel.

Structures on bedrock were damaged less than those on unconsolidated deposits. For example, large concrete buildings at Whittier, built on bedrock, received less damage although closer to the epicenter, than the concrete structures of Anchorage which were built on outwash gravel and clay.

All structures in Anchorage were subjected to intense seismic shaking during the earthquake. Many of the steel and concrete structures were severely damaged and one collapsed (fig. 18D). Some 

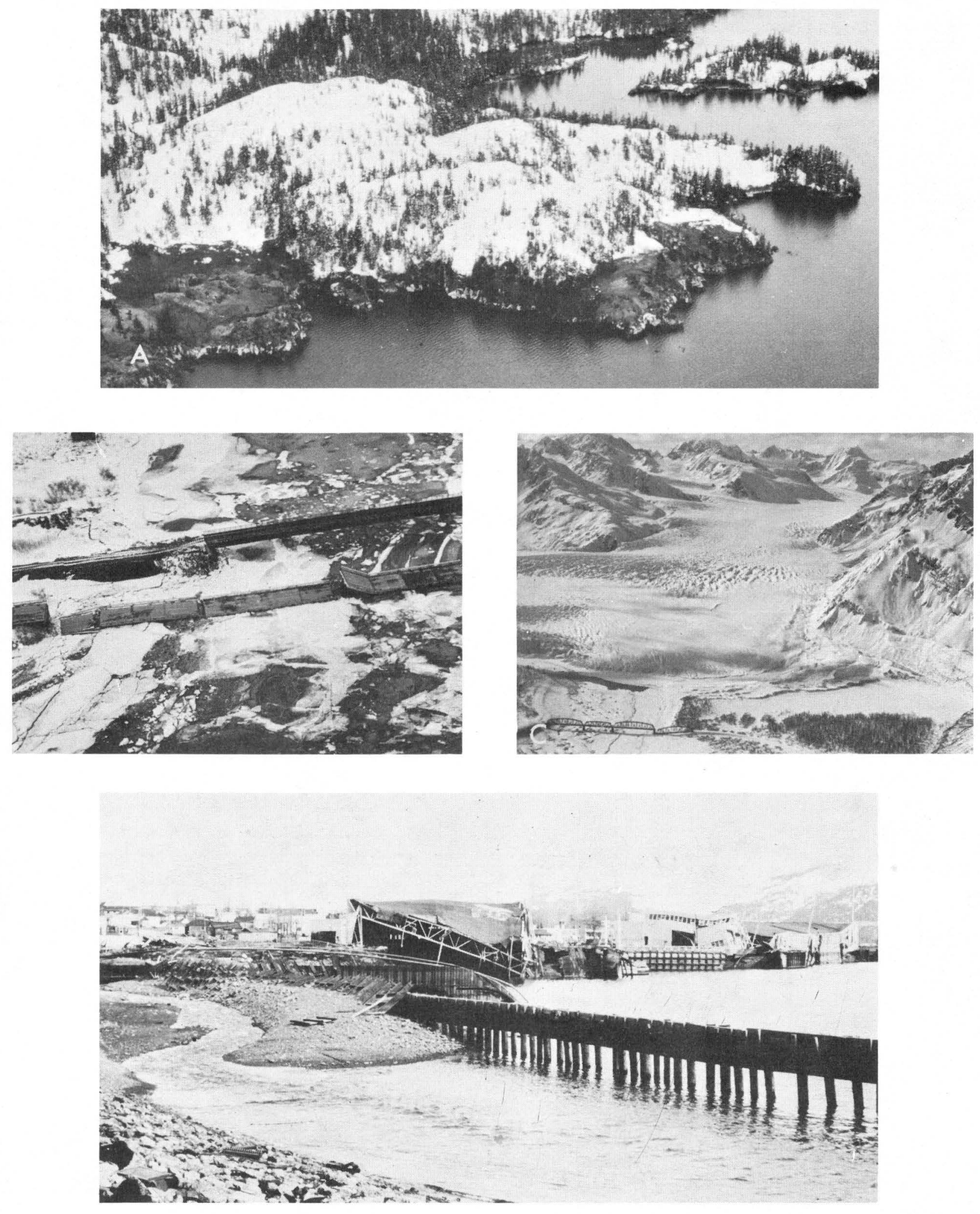

Figure 14. Photographs of damage to transportation routes and effects of large sea waves. A, Wave trim-line on north-facing bluffs of CULROSS ISLAND. $B$, Damage to railroad and highway bridge areas, 20-MILE RIVER. C, Damage to steel bridge crossing COPPER RIVER near Miles Glacier. D, Seismic sea wave damage at SEWARD. 


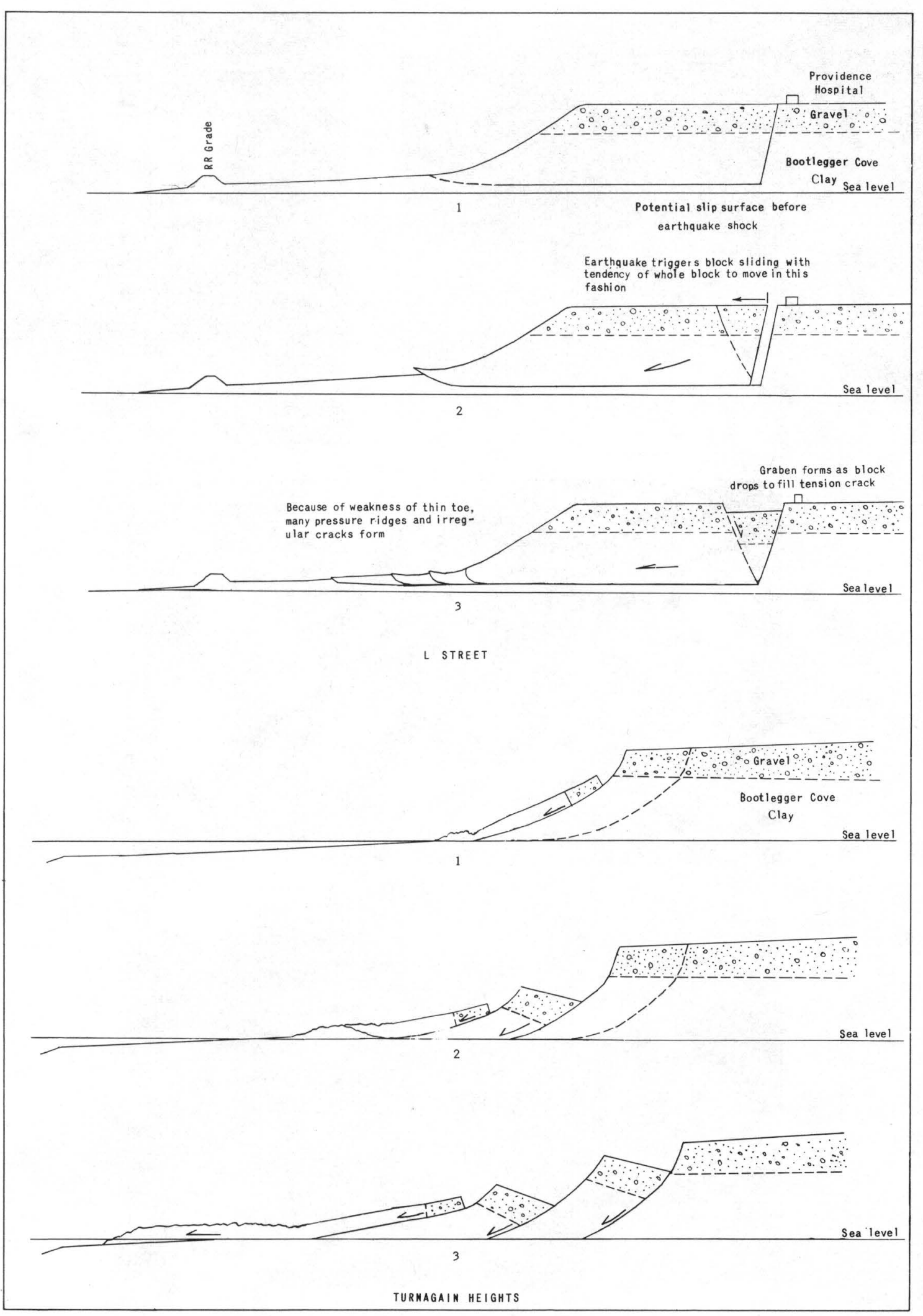

Figure 16. Diagrammatic sections showing probable development of L-Street and Turnagain Heights landslides in ANCHORAGE. 

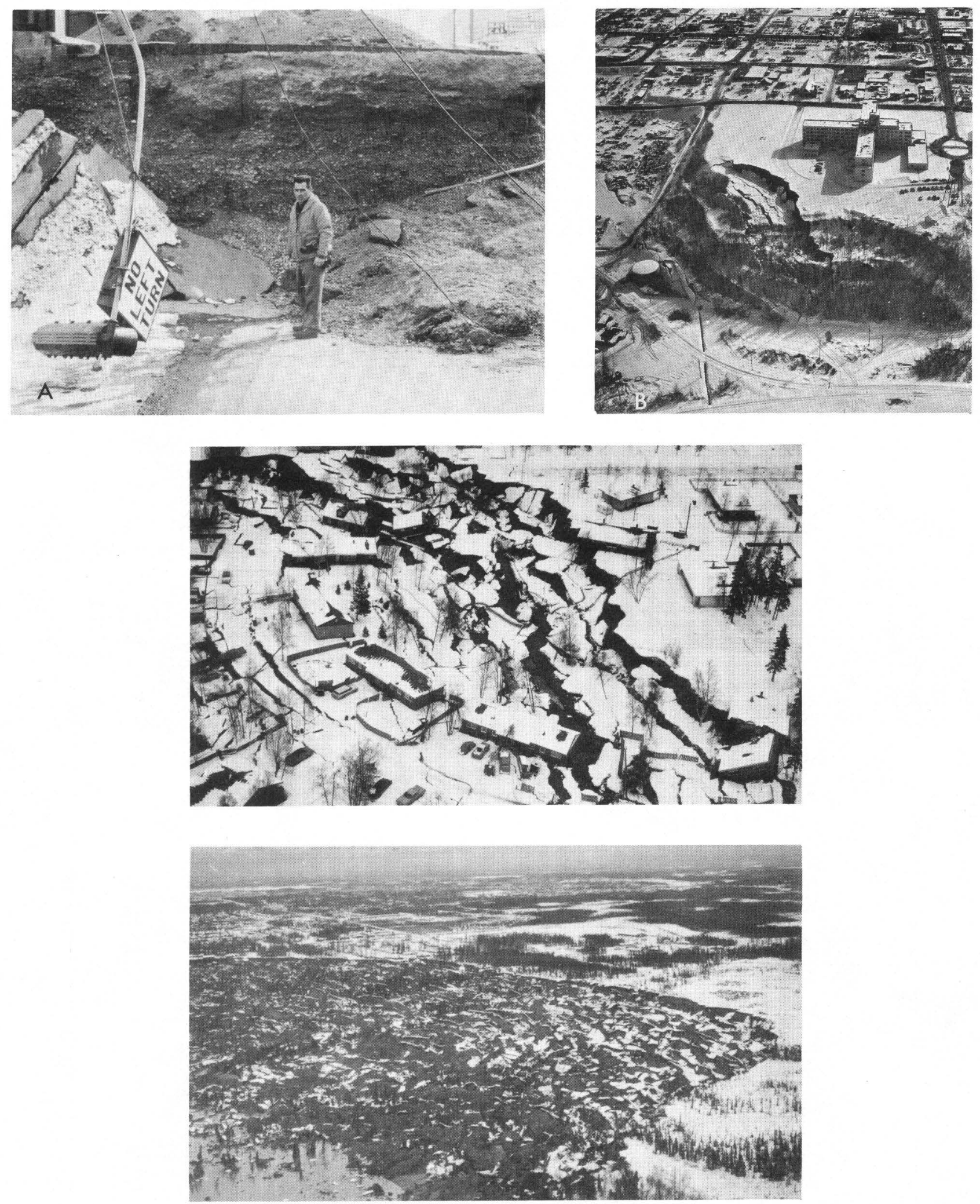

Figure 17. Photographs of destructive landslides in ANCHORAGE. A, Subsidence in the graben at the head of the Fourth Avenue slide. B, Landslide near Alaska Nature Hospital. C, D, East and west parts of the Turnagain slide. 

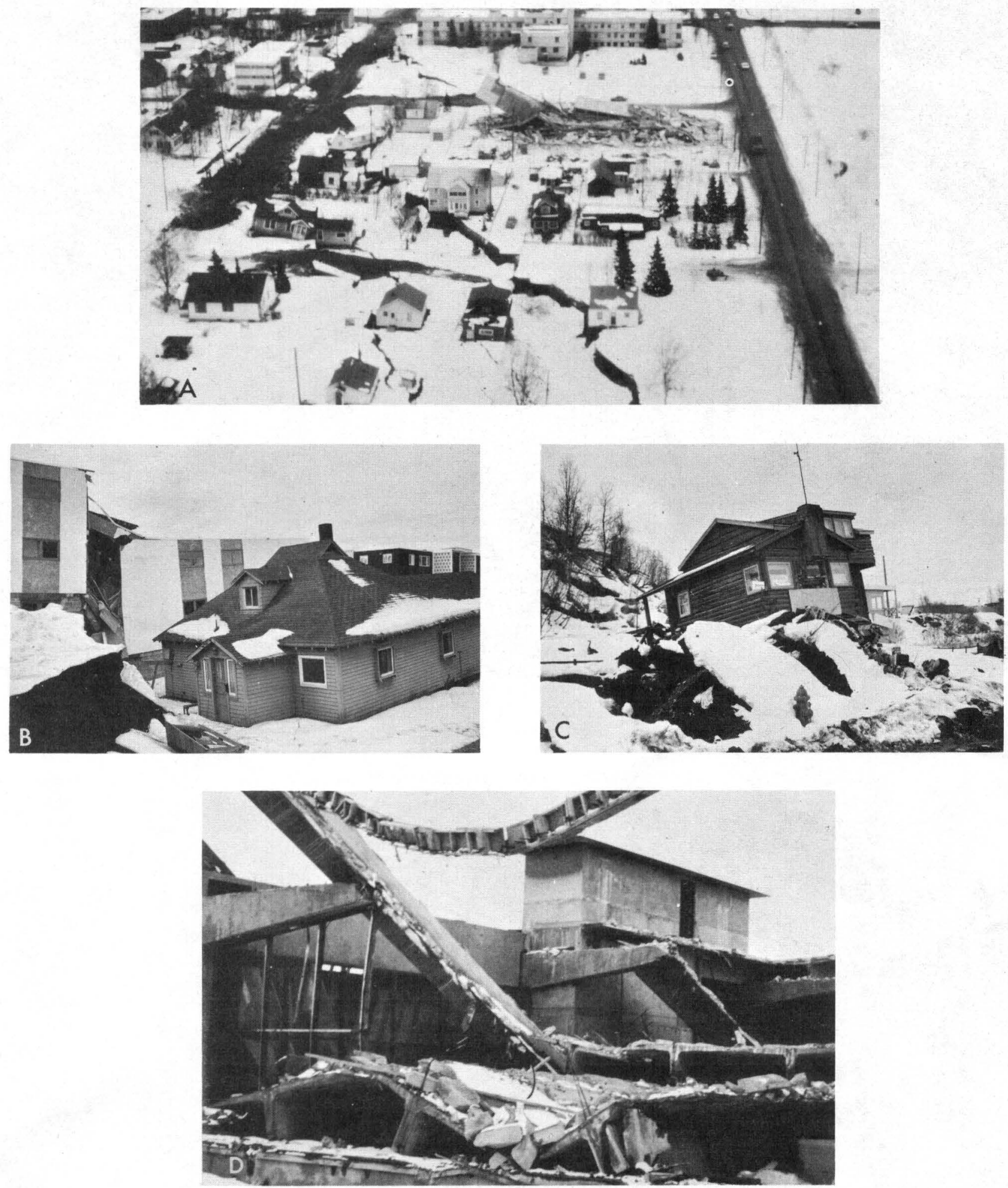

Figure 18. Photographs of destructive landslides and damage in ANCHORAGE. A, B, Graben at head of L Street landslide. C, Compressional ridge formed at toe of $\mathrm{L}$ Street landslide. $\overline{\mathrm{D}}$, Destruction by seismic shock of a partially complete concrete structure on unconsolidated deposits. 
Figure 19. Aerial photographs of WHITTIER and vicinity. A, 1948. B, April 3 , 1964. Note destruction of pier facilities. Dashed line shows high-water line. (U. S. Coast and Geodetic Survey photographs.) 


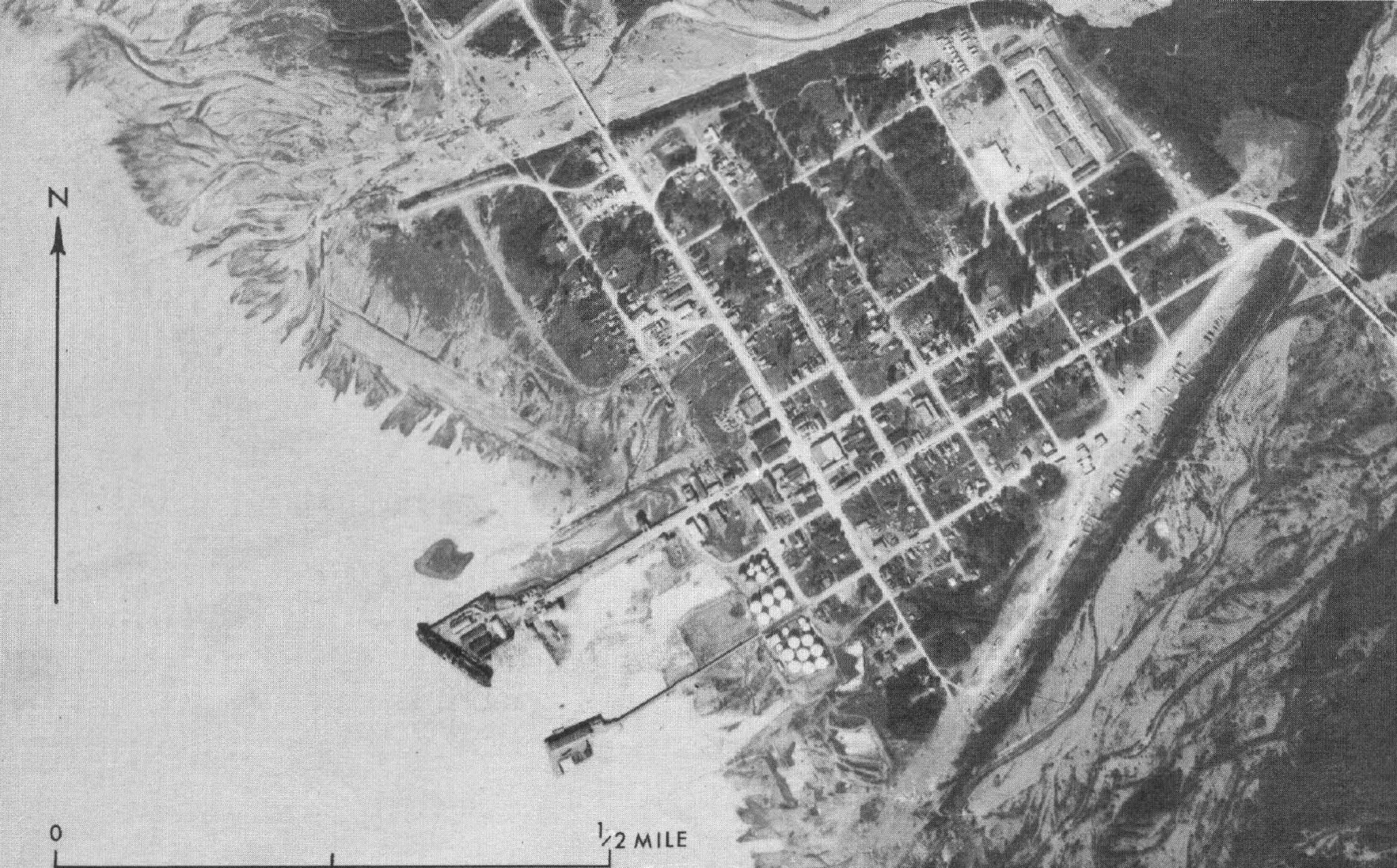

A

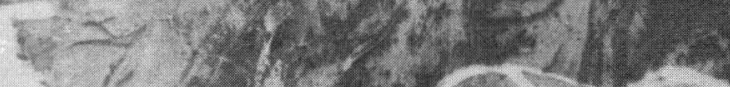

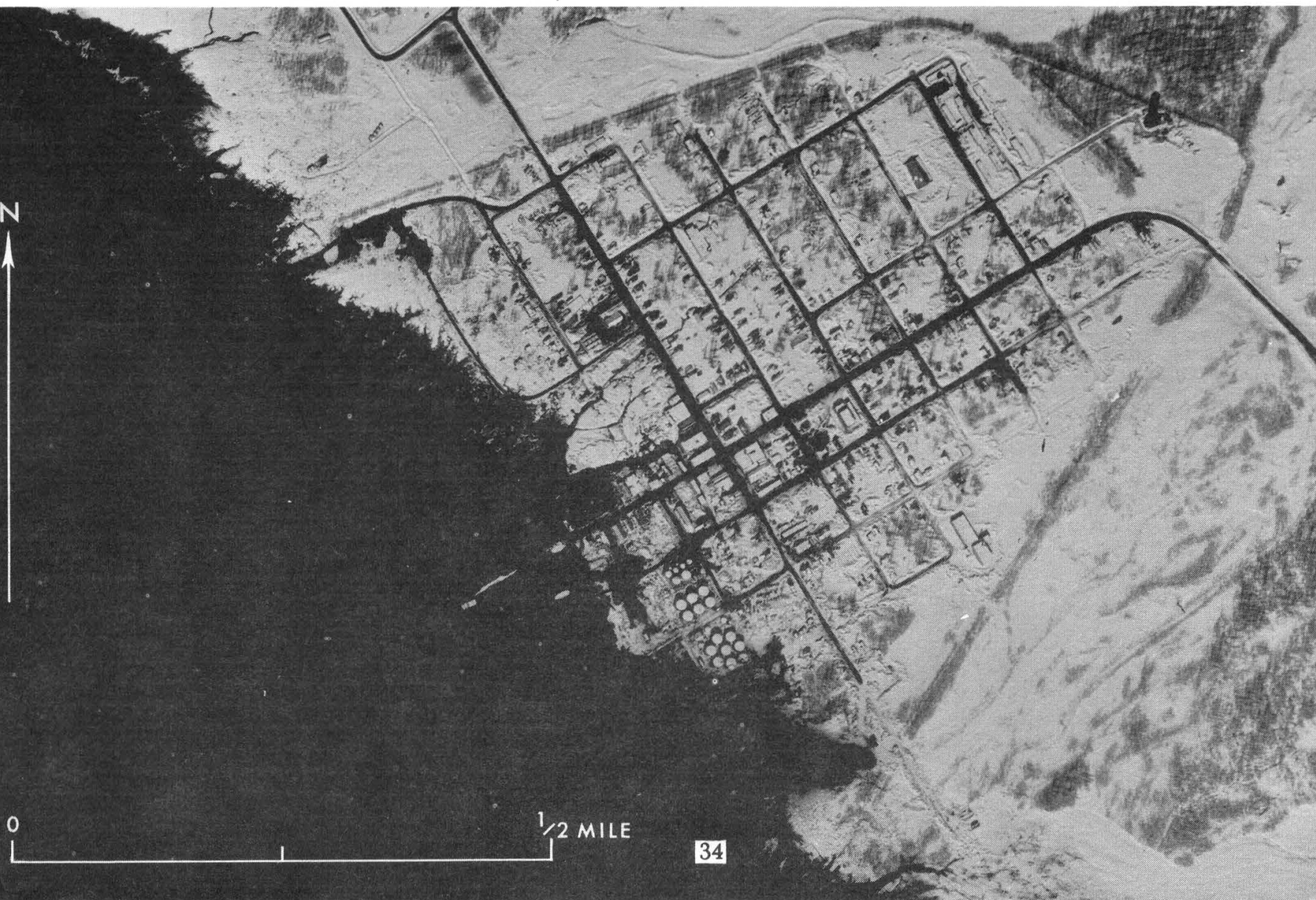


concrete-block structures were also damaged, a few severely. In contrast, wood-frame structures were generally much less damaged, or were unharmed.

\section{SUBMARINE LANDSLIDES IN FIORD DELTAS}

Submarine landsliding in fiord delta deposits was a ma jor geologic side effect of the March 27 earthquake, and it seems likely that if Prince William Sound had been heavily populated, this phenomenon would have been observed even more widely than it was. The susceptibility of the submarine slopes on fiord deltas to slide (or fail) under the influence of strong seismic shocks of long duration should be carefully studied before large buildings or other large structures are planned near the shorelines of such deposits.

\section{LAND-LEVEL CHANGES}

Land-level changes over at least 34,000 square miles of south-central Alaska have rendered obsolete all nautical charts and primary triangulation survey nets in the area. Shorelines that are lowered with respect to sea level were especially hard hit by the earthquake-generated waves of March 27 and 28, whereas the destructiveness of the waves in uplifted areas was substantially less. Regional subsidence has resulted in widespread inundation of low-lying coastal property and has jeopardized the safety of docking facilities, canneries, and other shoreline structures on Kodiak Island and the Kenai Peninsula. On the other hand, the uplifted areas, particularly Prince William Sound and Controller Bay, have had the usefulness of their harbors, channels, and shoreline installations serious ly impaired by the relatively lowered water levels.

\section{REFERENCES}

Condon, W. H., and Cass, J. T., 1958, Map of a part of the Prince William Sound area, Alaska, showing linear geologic features as shown on areal photographs: U. S. Geol. Survey Misc. Geol. Inv. Map I-273, scale $1: 125,000$.

Davis, T. N., 1960, A field report on the Alaska earthquake of April 7, 1958: Seismol. Soc. America Bull., v. 50, p. 489-510.

Gutenberg, Beno, and Richter, C. F., 1954, Seismicity of the earth and associated phenomena, $2 \mathrm{~d}$ ed.: Princeton, N. J., Princeton Univ. Press, $310 \mathrm{p}$.

Miller, R. D., and Dobrovolny, Ernest, 1959, Surficial geology of Anchorage and vicinity, Alaska: U.S. Geol. Survey Bull. 1093, 128 p.

U. S. Coast and Geodetic Survey, 1964, Preliminary report Prince William Sound, A lask an earthquakes, March-April 1964: Washington, D. C., U. S. Dept. Commerce, 100 p.

Figure 20. Aerial photographs of Valdez before and after the earthquake. $A$, 1954. B, April 4, 1964. Note the complete destruction on shoreline, harbor, and pier facilities. (U. S. Coast and Geodetic Survey photographs.) 




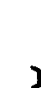

8
5
0
$\frac{\pi}{3}$
0
0
0
0
0

끔

$\bar{\gamma}$
2

m

저

$\stackrel{\rho}{c}$

鬲

!n

3

ก̊ำ

N

a

$\rightarrow$

ष

국

G.

윽

'

6

(1)

7

궂

동

일 